\title{
Netkennsla og stafræn tækni í grunnskólum á tímum farsóttar vorið 2020: Sýn kennara
}

\author{
Sólveig Jakobsdóttir, Salvör Gissurardóttir, \\ Skúlína Kjartansdóttir, Svava Pétursdóttir og Torfi Hjartarson \\ Abstract $>$ Um höfunda $\quad$ About the authors $>$ Heimildir
}

Á vormánuðum 2020 urðu miklar takmarkanir á grunnskólastarfi hér á landi vegna faraldurs COVID-19, skólum var víða skipt í sóttvarnahólf, hópastærðir takmarkaðar, nemendahópar sendir heim um skemmri eða lengri tíma og kennsla á völdum greinasviðum lögð af um skeið. Menntavísindasvið og Menntavísindastofnun Háskóla Íslands stóðu af pessu tilefni fyrir viðamikilli könnun á öllum skólastigum til að meta áhrif faraldursins á menntun og skólastarf. Hér er fjallað um pann hluta könnunarinnar sem sneri að notkun á stafrænni tækni á meðan hefðbundið skólastarf var skert með ýmsu móti pessa vormánuði og byggt á svörum 1550 kennara, sérkennara og leiðbeinenda við 151 grunnskóla. Markmið með peim hluta könnunarinnar var að draga fram og rýna áhrif faraldursins á netnotkun og beitingu stafrænnar tækni í starfi grunnskóla. Í ljós kom að meirihluti svarenda taldi skólana vel búna stafrænum verkfærum og starfsliðið vel undir pað búið að takast á við aukin tölvusamskipti, blandaða kennslu og netkennslu. Pó voru sumir peirrar skoðunar, ekki síst í hópi kennara á yngri stigum, að efla pyrfti búnað skóla og kunnáttu kennara á pessu sviði. Meirihluti kennara taldi að aðgengi nemenda að tækni heima fyrir dygði vel til samskipta og netnáms í faraldrinum en sumir kennarar, einkum á yngri stigum, virtust telja að nokkuð hefði skort á aðgengi að búnaði heima hjá nemendum. Niðurstöður sýna að miklar breytingar hafa orðið á kennsluháttum og nýtingu stafrænnar tækni meðan á faraldrinum hefur staðið. Skýrt kom 1 ljós aukning blandaðs náms og netnáms á unglingastigi, töluverð aukning á miðstigi og merkjanlegar breytingar allt niður á yngsta stig. Pá hafði faraldurinn bæði letjandi og hvetjandi áhrif á skapandi starf með hjálp stafrænnar tækni. Meirihluti svarenda taldi að reynslan í COVID-faraldrinum myndi breyta kennsluháttum í skólum peirra til frambúđar. Pátttakendum pótti mikilvægt að búa kennara undir aukna netkennslu og umtalsverður áhugi kom fram á að sækja einingabært nám um hagnýtar leiðir í notkun tækni í námi og kennslu. Niðurstöður benda til að aðstæður kennara, kunnátta og færni séu með ýmsu móti og efla purfi greiningu á stöðu stafrænnar tækni í grunnskólum.

Efnisorð: Blönduð kennsla, netkennsla, stafræn tækni, skólapróun, COVID-19faraldur

\section{Inngangur}

Í janúarlok 2020 gaf Alpjóðaheilbrigðisstofnunin út yfirlýsingu um alpjóðlegt neyðarástand vegna COVID-19 og undir miðjan mars var birt yfirlýsing um veirufaraldur á heimsvísu (World Health Organization, 2020). Fyrsta veirusýkingin greindist á Íslandi 28. febrúar (Sóttvarnalæknir, 2020) og í kjölfarið gripu stofnanir ríkis og sveitarfélaga til aðgerða. Í sameiginlegri yfirlýsingu sveitarfélaga 15. mars (Samband íslenskra sveitarfélaga, 2020) kom fram að íslenskt samfélag tækist á við veirufaraldur og að nauðsynlegt væri að grípa til aðgerða í skólastarfi. Mat sóttvarnalæknis 
og yfirvalda var að pýðingarmikið væri að leik- og grunnskólar störfuðu áfram pó að skólastarf raskaðist og yrði skilyrðum háð enda pyrfti að tryggja rétt nemenda til náms. Í kjölfarið fylgdu umfangsmiklar aðgerðir til að tryggja lágmarkssóttvarnir og stuðla að öryggi og velferð nemenda og kennara (reglugerð um takmörkun á skólastarfi vegna farsóttar nr. 958/2020). Starfsemi framhaldsskóla og háskóla tók einnig miklum breytingum og færðist nær alfarið á netið með breyttri og aukinni notkun upplýsingatækni (Duríður Jóna Jóhannsdóttir og Sólveig Jakobsdóttir, 2020).

Með viðbragðsáætlun Almannavarna í maí 2020 vegna heimsfaraldurs (Ríkislögreglustjóri og sóttvarnalæknir, 2020) var Mennta- og menningarmálaráðuneyti falin ábyrgð á skólahaldi, menningarstofnunum, ípróttum og æskulýðsstarfi í faraldrinum og forstöðumönnum fræðslustofnana gert að gera viðbragðsáætlun á óvissustigi, taka mið af aðstæðum, yfirfara „allar boðleiðir og gera áætlun um hvernig nýta megi sem best upplýsingamiðlun fræðsluaðila, svo sem símasvörun, tölvupóst, nettengd kennslukerfi, vefsíðu og samskiptamiðla“ (bls. 64). Á hættustigi var peim ætlað аð gera birgðaáætlun og semja verklagsreglur um ræstingar og viðbrögð við veikindum nemenda og starfsfólks, ásamt að bjóða nemendum í brotthvarfshættu stuðning námsráđgjafa pegar pví yrđi við komið. Á neyðarstigi var gert ráð fyrir að skólar héldu uppi starfsemi pegar unnt var og að starfslið skóla héldi áfram störfum pó að nemendur eða starfsmenn yrðu sendir heim vegna sóttvarnaráđstafana. Skólum var ætlað að skipuleggja kennslu og umsjón kennara með heimanámi á netinu til að leysa af hólmi eða styðja við nám og kennslu innan skólaveggja.

Skólar purftu með öðrum orðum að minnka eða leggja niður að hluta hefðbundið skólastarf og pví reiða sig meira en áður á notkun upplýsinga- og samskiptatækni og, par sem pað átti við, umbylta öllu fyrirkomulagi skólastarfsins með breyttum náms- og kennsluháttum. Erfitt er að henda reiður á öllum peim skipulagsbreytingum sem fylgdu faraldrinum á grunnskólastigi, enda voru pær bundnar aðstæðum og ákvörðunum í sveitarfélögum og einstökum skólum, en við mörgum kennurum blasti umbylting á kennsluháttum og tímabil tilrauna með nýjar aðferðir. Takmarka purfti aðgengi að skólunum, skólastarfi var víða skipt niður í sóttvarnahólf, fækka purfti í sumum nemendahópum, valdir nemendahópar, oft eldri nemendur, voru sendir heim um lengri eða skemmri tíma og kennsla í sumum greinum, einkum list- og verkgreinum, var felld niður, að hluta vegna smithættu við not á búnaði. Kennsla dróst pví saman að einhverju leyti, samskipti innan og utan skóla urðu með öðrum hætti en áður og hluti kennslu og samskipta, bæði við nemendur og foreldra, fór fram á netinu, einkum á eldri stigum (Kristín Jónsdóttir, 2020; Ruth Jörgensdóttir Rauterberg og Anna Björk Sverrisdóttir, 2020; Salvör Nordal o.fl., 2020). Í rannsókn okkar er engin tilraun gerð til að kortleggja sóttvarnaráđstafanir í skólunum heldur leitast við að greina hugmyndir og viðhorf starfsfólks í grunnskólum um áhrif faraldursins á náms- og kennsluhætti með tilliti til notkunar á stafrænni tækni og pýðingu peirra breytinga hvað snertir nemendur og kennara, aðbúnað, námsumhverfi, stuðning og starfspjálfun við pessar lykilstofnanir í íslensku menntakerfi. Byggt er á hluta rafrænnar spurningakönnunar á vegum Menntavísindasviðs og Menntavísindastofnunar Háskóla Íslands síðla vors 2020, umfangsmikillar spurningakönnunar sem náði til fleiri hópa og tengdist fleiri rannsóknum í faraldrinum.

\section{Baksvið rannsóknar og rannsóknarspurningar}

Kennsla í íslenskum grunnskólum hefur að mestu átt sér stað innan kennslustofu, nemendur hafa mætt í kennslustundir og bækur og önnur skrifleg gögn verið í forgrunni (Ingvar Sigurgeirsson o.fl., 2014). Í rannsókn um starfshætti í grunnskólum á hrunárunum 2009 til 2011 kom í ljós afar takmörkuð nýting á upplýsingatækni í kennslustundum enda var aðgengi nemenda að tölvubúnaði lítið (Sólveig Jakobsdóttir o.fl., 2014). Í vettvangsathugunum í kennslustundum kom fram að „,tölvur voru á staðnum í 78\% tilvika, skjávarpi í 41\% tilvika, prentari í 35\% tilvika og snjalltafla í 2\% tilvika“" (Sólveig Jakobsdóttir o.fl., 2014, bls. 289). Í 51\% tilvika var einungis til ráđstöfunar ein tölva fyrir kennara en stundum (18\%) par til viðbótar ein eða tvær nemendatölvur. 
Nokkrum árum eftir hrun tók að gæta áhrifa fartæknibylgju sem fylgdi nýjum og meðfærilegum snjalltækjum á borð við spjaldtölvur og snjallsíma. Athafnakostir pessara nýju verkfæra vöktu áhuga skólafólks og menntayfirvalda víða um heim (t.d. Attewell o.fl., 2015; Bannister, 2015; Bannister o.fl., 2013; European School Network, 2012; Vuorikari o.fl., 2011) og sú varð einnig raunin hér á landi (Sólveig Jakobsdóttir o.fl., 2014). Í Norðlingaskóla var farið að nýta spjaldtölvur árið 2012 og lagt kapp á að unglingar hefðu í námi sínu persónuleg afnot af nettengdri tölvu í anda kennslufræðinnar 1:1 eða eitt tæki á nemanda (Sólveig Jakobsdóttir og Skúlína Hlíf Kjartansdóttir, 2015). Skömmu síðar fóru einstök sveitarfélög, einna fyrst Hvalfjarðarsveit 2013 og Kópavogsbær 2015, að innleiða slíka notkun á spjaldtölvum í grunnskólum, fyrst á unglingastigi og síðar á miðstigi (Heiðarskóli, 2021; Kópavogsbær, e.d.). Dessi próun nær nú til skóla víða um land, hefur breytt aðstöðu til náms, opnað skólastarf fyrir albjóðlegum áhrifum og fært inn í skólastarfið námsefni víðs vegar að af netinu. Pá hefur aðstaða til náms batnað með styrkingu práðlausra nettenginga og fyrir tilstuðlan námsumsjónar- og kennslukerfa (Sólveig Jakobsdóttir og Puríður Jóhannsdóttir, 2018).

Fjarnám á grunnskólastigi hefur ekki verið umfangsmikið hér á landi. Helst er að nefna fjarkennslu á netinu í tungumálum (einkum norsku og sænsku) en hún hefur verið samfellt í boði í um tvo áratugi á vegum Tungumálaversins (Sólveig Jakobsdóttir og Duríður Jóhannsdóttir, 2018). Dá má nefna skammtímaverkefni um samstarf fámennra skóla á landsbyggðinni um fjarnám (Rúnar Sigpórsson, 2000, 2003; Trausti Dorsteinsson o.fl., 2006; Puríður Jóhannsdóttir og Sólveig Jakobsdóttir, 2011). Einnig hafa grunnskólanemendur getað tekið valáfanga í framhaldsskólum yfir netið (Sólveig Jakobsdóttir og Duríður Jóhannsdóttir, 2010; Torfi Hjartarson, 2005). Alpjóðleg samstarfsverkefni á netinu hafa líka lengi verið vinsæl í íslenskum leik-, grunn- og framhaldsskólum, nú síðustu ár ekki síst undir merkjum eTwinning, par sem skólar, kennarar og nemendur um alla Evrópu eiga með sér rafrænt samstarf, oftast um vel afmörkuð verkefni (Callels o.fl., 2016; Kearney og Gras-Velázquez, 2015). ${ }^{1}$

Blandað nám á staðnum og netinu stutt námsumsjónarkerfum hefur svo verið að próast, í fyrstu við stöku grunnskóla par sem kennari og nemendur nýttu námsumsjónarkerfi á borð við Moodle (Ágúst Tómasson, 2015) og á síðustu árum víðar og pá einkum með stuðningi af námsumsjónarkerfinu Google Classroom (t.d. Oddur Ingi Guðmundsson, 2019) og stundum spjaldtölvuappinu Seesaw par sem halda má utan um verkefni og verkefnaskil. Forsendur til að nýta netið í skólastarfi í bland við aðra kennslu hafa batnað mikið með auknu aðgengi nemenda að tölvubúnaði síðustu ár, spjaldtölvum, að mestu frá Apple, stundum snjallsímum í eigu nemenda sjálfra en einnig léttum fartölvum skóla til einfaldra nota, að mestu frá Google.

Tæknipróun undanfarinna ára hefur verið ör og beint sjónum skólafólks að stafrænni hæfni kennara. Evrópuráðið hefur skilgreint hæfni kennara á sex sviðum og í 22 atriðum. Sviðin eru fagleg virkni, stafran verkfari, nám og kennsla, námsmat, valdefling nemenda og stafraen haeni nemenda. Ljóst er að kennarar eiga að vera færir um að skipuleggja kennslu, verkefni og samskipti í stafrænu umhverfi og geta beitt kennsluháttum með stuðningi af tækni par sem pað á við (Redecker, 2017). Ekki er samt ljóst í skilgreiningu Evrópuráđsins né öðrum hæfnirömmum (Kelentrić o.fl., 2017) að hæfnin taki til kennslu sem teygir sig út fyrir veggi skólastofunnar. Rannsóknir hafa sýnt að jafnvel nýir kennarar, sem pó hafa alist upp í tæknivæddu pjóðfélagi, búa oft yfir lítilli stafrænni hæfni (Guillén-Gámez o.fl., 2020; Gréta Björk Guðmundsdóttir og Hatlevik, 2018). König o.fl. (2020) lögðu könnun um petta efni fyrir 165 kennara sem höfðu fengið rík tækifæri í námi sínu til að efla stafræna hæfni sína og voru á sínu fyrsta eða öðru starfsári pegar veirufaraldur kallaði á netkennslu. Niðurstöður peirra sýndu að kennurunum gekk vel að halda sambandi við nemendur sína á neti, leggja fyrir verkefni og veita endurgjöf en síður að leggja upp kennslu og námsmat á netinu.

Umfjöllun um tækni og stafræna miðlun í kennaramenntun hefur einhver áhrif á færni og viðhorf kennara og starfandi kennarar hafa margir í farteskinu áralöng kynni af að vera fjarnemar í kennaramenntun. Pá geta starfssamfélög gegnt mikilvægu menntunarhlutverki í starfspróun ${ }^{1}$ Sumarið 2021 voru 318 íslenskir skólar skrádir á vefsetri eTwinning (https://www.etwinning.net), 1.792 kennarar og 1.102 verkefni. Heildar-
fjöldi evrópskra kennara á vefsetrinu var yfir 940.000 og fjöldi skóla um 220.000. 
(Wenger, 1998) og huga parf að pví hvernig samfélagsmiðlar styðja starfsnám og endurmenntun (Wenger o.fl., 2009). Kennarar hafa myndað með sér óformleg starfssamfélög á samfélagsmiðlum og víða er í próunarstarfi lögð áhersla á að ýta undir og styðja við slíka faghópa á netinu (Skúlína Hlíf Kjartansdóttir o.fl., 2020; Sólveig Jakobsdóttir, 2020; Sólveig Jakobsdóttir o.fl., 2013). Nefna má menntabúđir sem eiga rætur hérlendis í kennaramenntun (Sólveig Jakobsdóttir, 2020) og kennarar um allt land hafa byggt upp jafningjafræðslu með pessum hætti um upplýsingatækni í skólastarfi. Vorið 2020 var einnig gripið til pess ráðs að halda fjarmenntabúðir til stuðnings við kennara í COVID-faraldrinum á vegum Menntavísindasviðs Háskóla Íslands og Kennaradeildar Háskólans a Akureyri í samvinnu við fleiri aðila (Sólveig Jakobsdóttir, 2020, Sólveig Jakobsdóttir o.fl., 2021).

Hvað starfspróun á pessu sviði náms og kennslu í íslenskum grunnskólum snertir fer mikið eftir sveitarfélögum hvort hugað er að henni eða stutt við hana með einhverju móti (Allyson Macdonald o.fl., 2005; Sólveig Jakobsdóttir o.fl., 2014). Í einhverjum tilvikum eru kennsluráđgjafar á sviði upplýsingatækni starfandi við hvern skóla og hafa verið lengi, líkt og í Garðabæ (Torfi Hjartarson, 2005) eða í tengslum við innleiðingu snjalltækja á seinni árum, líkt og í Kópavogi (Sigurður Haukur Gíslason, 2017) og með áherslu á ýmsar fleiri tækninýjungar, líkt og í Reykjavík (Skúlína Hlíf Kjartansdóttir o.fl., 2020). Telja má víst að stuðningur við kennara í COVID-faraldrinum litist af pessu. Í Kópavogi voru til að mynda gefnar út leiðbeiningar um skipulag netkennslu vegna faraldursins (Menntasvið Kópavogsbæjar, 2020) en reikna má með að víða sé minna um stuðning af pví tagi. Um leið parf að hafa í huga að fleira hefur áhrif á færni og undirbúning kennara hvað petta varðar.

Rétt er að minna á að prátt fyrir takmarkað aðgengi að tölvubúnaði fyrstu áratugi tölvunotkunar í grunnskólum bauð tæknin upp á marga áhugaverða kosti, vinnu með kennsluforrit og leiki, gagnaleitir og gagnavinnslu, efnisgerð og ýmiss konar hönnun, samskipti og miðlun, prautalausnir og forritun, svo eitthvað sé nefnt (Sólveig Jakobsdóttir o.fl., 2014). Degar snjalltækin komu svo til sögunnar og tölvunotkun í skólum varð almennari voru áhugasamir kennarar fljótir að átta sig á pví að mikill skortur væri á stafrænum kennslugögnum á íslensku sem komið gætu að gagni í skólastarfinu (Sólveig Jakobsdóttir og Skúlína Hlíf Kjartansdóttir, 2015). Ýmis sprotafyrirtæki tóku að bjóða upp á íslenskar lausnir fyrir spjaldtölvur og jafnvel markaðssetja pær á albjóðlegum vettvangi (Gebo Kano, 2021). Dá var ráðist í átak á sviði máltækni með pað fyrir augum að íslenska gæti orðið valkostur í tækniheiminum (Anna Björk Nikulásdóttir o.fl., 2017). Á allra síðustu árum hafa sköpunarsmiðjur (e. makerspaces) rutt sér rúms í skólastarfi (Skúlína Hlíf Kjartansdóttir o.fl., 2020) og til framtíðar litið má gera ráð fyrir að próun fjölpátttökuleikja og sýndarveruleikatækni geti haft töluverða pýðingu á ýmsum starfssviðum menntunar (sjá t.d. EVE Online, 2021).

Margt er óljóst um notkun tækni við nám og kennslu í grunnskólum yfirleitt og á tímum heimsfaraldurs sérstaklega en með rannsókn okkar er reynt að varpa ljósi á stöđu og próun tækninotkunar pegar takmarka purfti hefðbundið skólastarf vegna farsóttarinnar. Leitast er við að svara eftirfarandi rannsóknarspurningum um sýn og reynslu kennara á yngsta stigi, miðstigi og unglingastigi grunnskóla:

Hvernig telja grunnskólakennarar og starfslið peirra grunnskóla í stakk búna til að beita stafrænum verkfærum, blandaðri kennslu og fjarkennslu?

Hvernig beittu grunnskólakennarar stafrænni tækni, blandaðri kennslu og fjarkennslu í viðbrögðum sínum við COVID-faraldrinum?

Hvaða áhrif telja grunnskólakennarar að faraldurinn hafi haft á náms- og kennsluhætti í grunnskólum og próun skólastarfs til lengri tíma litið?

Par sem breytingar á kennslu vegna sóttvarnaaðgerða réðust mikið af aldri nemenda voru rannsóknargögn greind eftir aldursstigum. 


\section{Aðferð}

\section{Pátttakendur og framkvæmd}

Menntavísindastofnun Háskóla Íslands sendi boð á 8597 netföng starfsmanna 157 grunnskóla um pátttöku í könnun á áhrifum COVID-faraldursins á menntakerfið vorið 2020 (Menntavísindastofnun Háskóla Íslands, 2020). Könnunin var á netinu (í Qualtrics-kerfinu) og opin 27. apríl til 26. maí. Svör bárust frá 151 skóla, 1590 einstaklingum sem störfuðu við kennslu (kennurum, sérkennurum og leiðbeinendum) og 175 skólastjórnendum. Áætlað er að svarhlutfall hafi verið um 34\%. Í pessari grein er byggt á svörum 1550 pátttakenda, allra kennara, sérkennara og leiðbeinenda sem gáfu til kynna á hvaða aldursstigum peir kenndu (97,5\% af heildarfjölda svarenda við kennslu). Skipta má pessum 1550 starfsmönnum upp í fjóra hópa eftir pví á hvaða stigi eða stigum peir kenndu: $\mathrm{Y}=$ yngsta stigi eingöngu, $\mathrm{M}=$ miðstigi eingöngu, $\mathrm{U}=$ unglingastigi eingöngu, $2+=$ tveimur eða fleiri stigum. Í Töflu 1 kemur fram fjöldi og hlutfall pátttakenda í hverjum hópi en peir voru nokkuð svipaðir að stærð. Y-hópurinn var fjölmennastur með 466 svarendur (30,1\%) en M-hópurinn fámennastur með 325 svarendur (21\%). Í Töflu 1 má einnig sjá samsetningu hópsins með tilliti til starfs og kyns. Kennarar voru 69-78\% í hverjum hópi, lægsta hlutfall í hópi 2+. Sérkennarar voru 14-20\%, með hæst hlutfall í 2+; leiðbeinendur voru 8-13\% með lægsta hlutfall í U-hópnum. Konur voru flestar á yngsta stiginu, 97\%, 89\% á miðstigi, 81\% í 2+ hópnum og $73 \%$ á unglingastiginu.

Tafla 1. Dátttakendahópar flokkaðir eftir aldursstigi: Fjöldi, hlutfall og samsetning.

\begin{tabular}{|c|c|c|c|c|}
\hline Hópur & Fjöldi & $\begin{array}{l}\text { Hlutfall } \\
(\%)\end{array}$ & $\begin{array}{l}\text { Samsetning hóps: } \\
\text { Starf }\end{array}$ & $\begin{array}{l}\text { Samsetning hóps: } \\
\text { Kyn }\end{array}$ \\
\hline $\begin{array}{l}\text { Y } \\
\text { kenndu eingöngu á yngsta stigi }\end{array}$ & 466 & 30,1 & $\begin{array}{l}\text { Kennarar 72\% } \\
\text { Sérkennarar 15\% } \\
\text { Leiðbeinendur } 13 \%\end{array}$ & $\begin{array}{l}\text { Konur } 97 \% \\
\text { Karlar 3\% }\end{array}$ \\
\hline $\begin{array}{l}\text { M } \\
\text { kenndu eingöngu á miðstigi }\end{array}$ & 325 & 21,0 & $\begin{array}{l}\text { Kennarar } 74 \% \\
\text { Sérkennarar } 14 \% \\
\text { Leiðbeinendur } 12 \%\end{array}$ & $\begin{array}{l}\text { Konur } 89 \% \\
\text { Karlar } 11 \%\end{array}$ \\
\hline $\begin{array}{l}\text { U } \\
\text { kenndu eingöngu á unglingastigi }\end{array}$ & 372 & 24,0 & $\begin{array}{l}\text { Kennarar } 78 \% \\
\text { Sérkennarar 14\% } \\
\text { Leiðbeinendur 8\% }\end{array}$ & $\begin{array}{l}\text { Konur } 73 \% \\
\text { Karlar } 27 \%\end{array}$ \\
\hline $\begin{array}{l}2+ \\
\text { kenndu á tveimur eða fleiri stigum }\end{array}$ & 387 & 25,0 & $\begin{array}{l}\text { Kennarar 69\% } \\
\text { Sérkennarar 20\% } \\
\text { Leiðbeinendur 11\% }\end{array}$ & $\begin{array}{l}\text { Konur } 81 \% \\
\text { Karlar } 19 \%\end{array}$ \\
\hline
\end{tabular}

\section{Spurningalisti}

Á spurningalistanum voru bæði fjölvalsspurningar og opnar spurningar frá nokkrum rannsóknarhópum og beindust að mismunandi páttum skólastarfsins (sjá Menntavísindastofnun Háskóla Íslands, 2020). Spurningar okkar voru lagðar fram á vegum Rannsóknarstofu í upplýsingatækni og miðlun og snúast um stöðu stafrænnar tækni innan skólanna, not af henni í faraldrinum, blandaða kennslu og fjarkennslu, stuðning við starfsfólk, álitamál og áskoranir, jákvæða reynslu og hugmyndir um próun til framtíðar.

\section{Gagnaúrvinnsla}

Við gagnaúrvinnslu var beitt lýsandi tölfræði en kí-kvaðrat próf voru gerð til að skoða mun á svörum eftir aldursstigum (4 flokkar). Svör við opinni spurningu um skapandi starf voru kóðuð og pemagreind. 


\section{Niðurstöður}

\section{Hvernig voru skólar í stakk búnir til að beita blandaðri kennslu og fjarkennslu?}

Skólarnir virtust, af svörum kennara við spurningum að dæma, að mörgu leyti vel í stakk búnir til að beita blandaðri kennslu og fjarkennslu. Pá var litið til stafrænna verkfæra, starfsliðs skóla og aðgengis nemenda að tækni heima fyrir.

Spurt var hversu vel eða illa skólinn væri búinn stafrænum verkfærum (tækjum og hugbúnaði) til að takast á við aukin tölvusamskipti eða fjarkennslu. Svarhlutfall var um 67\%. Marktækur munur var á svörum eftir aldursstigum $\left(\chi^{2}(18, N=1042)=39,56, p=0,002\right)$. Svör má sjá á Mynd 1

60

50

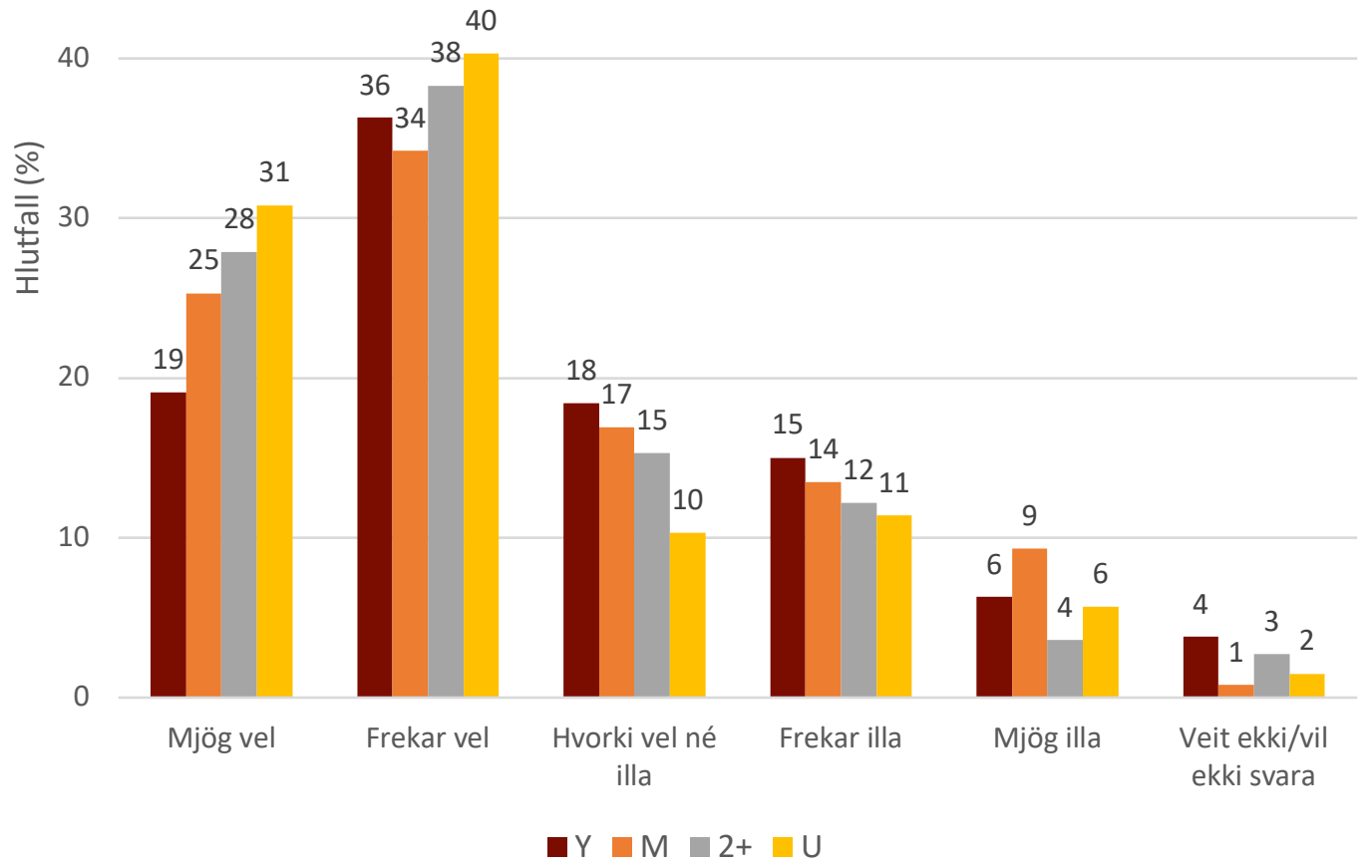

Mynd 1. Svör kennara eftir aldursstigum ( $Y=$ yngsta stig, $M=$ miðstig, $2+=$ kennsla á fleiri en einu stigi, $\mathrm{U}=$ unglingastig) við spurningunni: Hversu vel eða illa er skólinn búinn stafrænum verkfærum (tækjum og hugbúnaði) til að takast á við aukin tölvusamskipti eða fjarkennslu?

Á myndinni kemur fram að meirihluti allra hópa (55-71\%) taldi skólana mjög vel eða frekar vel búna af stafrænum verkfærum en unglingastigskennararnir voru mest sammála. Um 31\% voru mjög sammála og 40\% frekar sammála. Á meðan 19\% kennara á yngsta stigi voru mjög sammála og 36\% frekar; 25\% miðstigskennara mjög sammála og 34\% frekar; og 28\% peirra sem kenndu á fleiri en einu stigi mjög sammála en 38\% frekar. Á hinn bóginn voru 16-23\% kennara sem töldu pá frekar eða mjög illa búna. Um 10-18\% hópanna svöruðu svo „Hvorki vel né illa“.

Spurt var um starfslið skólans, hversu vel eða illa pað virtist búið undir að takast á við aukin tölvusamskipti eða fjarkennslu. Svarhlutfall var um 67\%. Svör má sjá á Mynd 2. Rannsókn- 
arhópurinn var hér að fiska eftir upplýsingum um hvernig starfsfólk væri í stakk búið til að takast á við breytingar á pessu sviði (e. preparedness) en vel má vera að einhverjir hafi talið að spurt væri hversu vel væri staðið að undirbúningi á borð við pjálfun eða upplýsingagjöf.

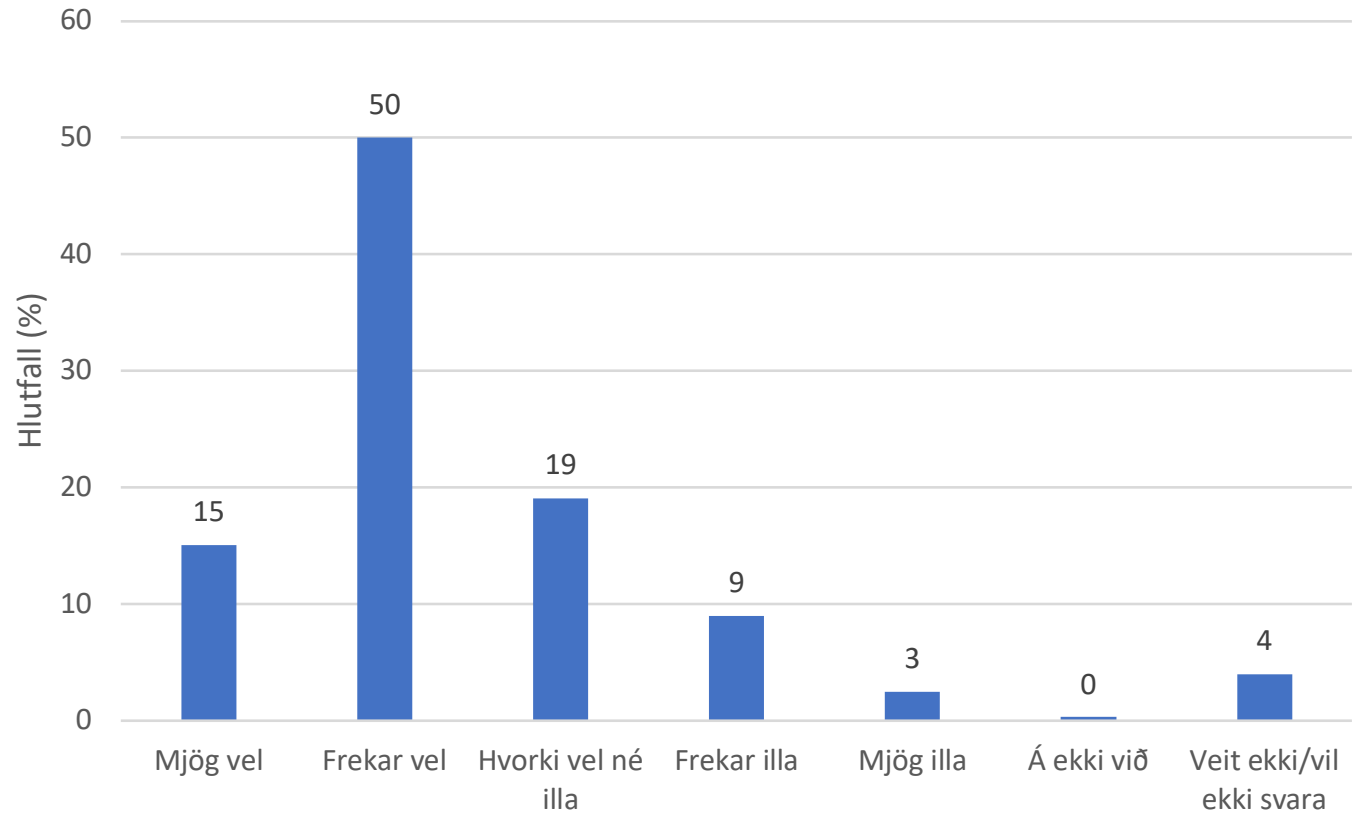

Mynd 2. Svör kennara við spurningunni: Hversu vel eða illa virðist starfslið skólans búið undir að takast á við aukin tölvusamskipti eða fjarkennslu?

Ekki var marktækur munur eftir aldursstigum í svörum við pessari spurningu. Rúmlega tveir priðju hlutar (65\%) töldu starfslið skólanna mjög vel (15\%) eða frekar vel (50\%) undirbúið. Um 19\% svöruðu „Hvorki vel né illa“ á meðan 9\% töldu starfsmenn frekar illa undirbúna og 3\% til viðbótar mjög illa undirbúna.

Pá var spurt hvernig aðgengi nemenda að tækni heima fyrir virtist duga til samskipta eða netnáms í faraldrinum. Svarhlutfall var 66\%. Á heildina litið taldi töluverður meirihluti (61\%) að aðgengi nemenda að tækni dygði vel, 17\% mjög vel og 44\% frekar vel. Um 14\% töldu að hann dygði hvorki vel né illa en $5 \%$ frekar illa og $1 \%$ mjög illa. Marktækur munur var á svörum eftir aldursstigum $\left(\chi^{2}(18, N=1027)=146,97, p<0,001\right)$. Svör hópanna má sjá á Mynd 3. Par sést að mun hærra hlutfall unglingastigskennara en annarra hópa taldi aðgengið duga vel (81\%), 25\% töldu aðgengið duga mjög vel og 56\% frekar vel á meðan sambærileg hlutföll hjá kennurum á yngsta stigi voru 8 og 34\% (42\%). Miðstigskennarar og peir sem kenndu á tveimur eða fleiri stigum voru parna mitt á milli hinna hópanna tveggja. 


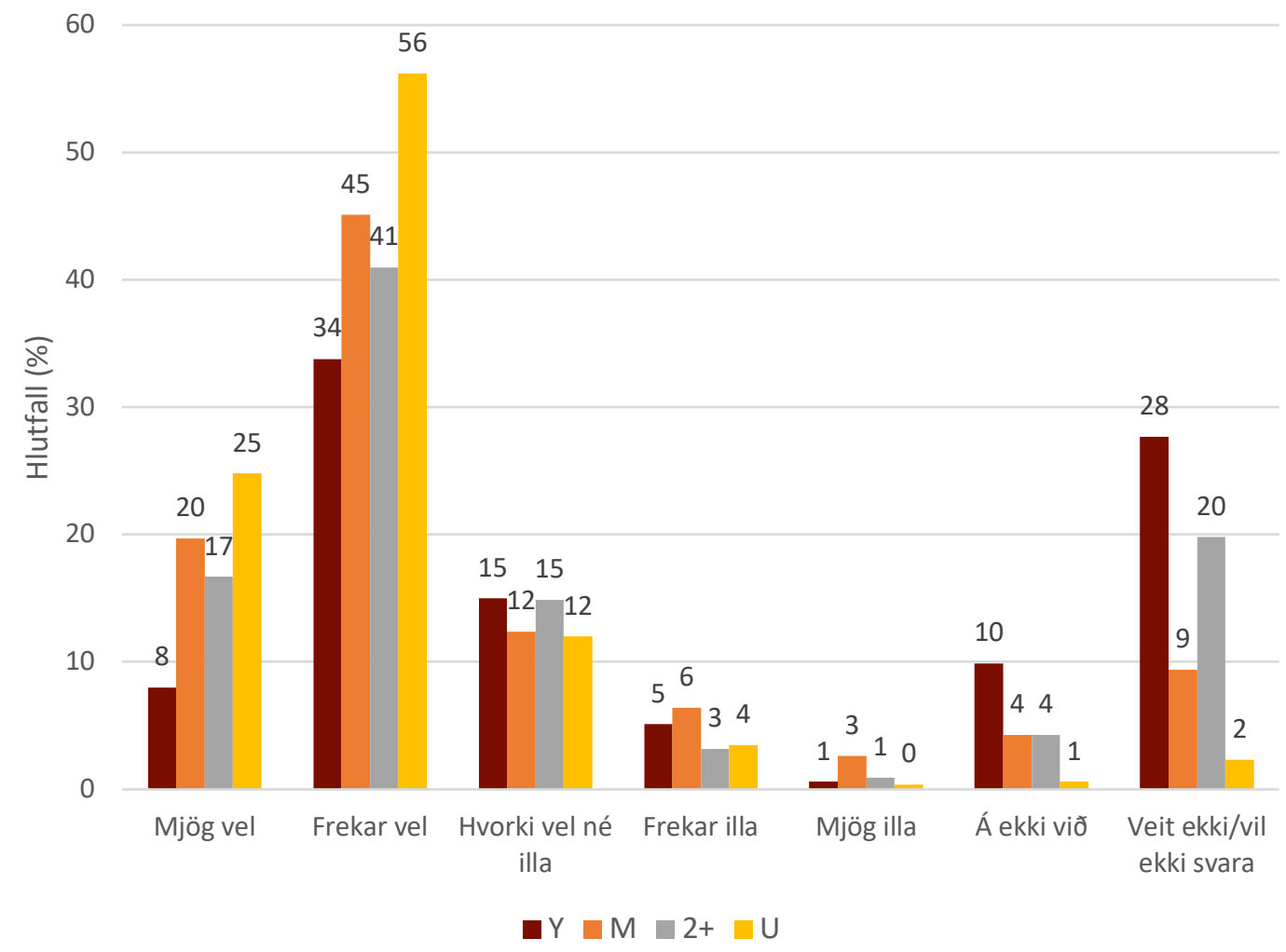

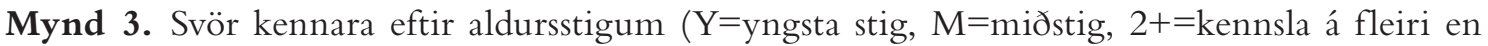
einu stigi, $U=$ unglingastig) við spurningunni: Hvernig virðist aðgengi nemenda að tækni heima fyrir duga til samskipta eða fjarnáms í faraldrinum?

\section{Nýting stafrænnar tækni, blönduð kennsla og fjarkennsla}

Spurt var hversu mikil eða lítil áhrif fólki fyndist breytingar vegna veirufaraldursins hafa haft á kennsluhætti í skólanum. Svarhlutfall var um 81\%. Marktækur munur var á svörum eftir aldursstigi $\left(\chi^{2}(12, N=1255)=30,94, p=0,002\right)$. Svör má sjá á Mynd 4.

60

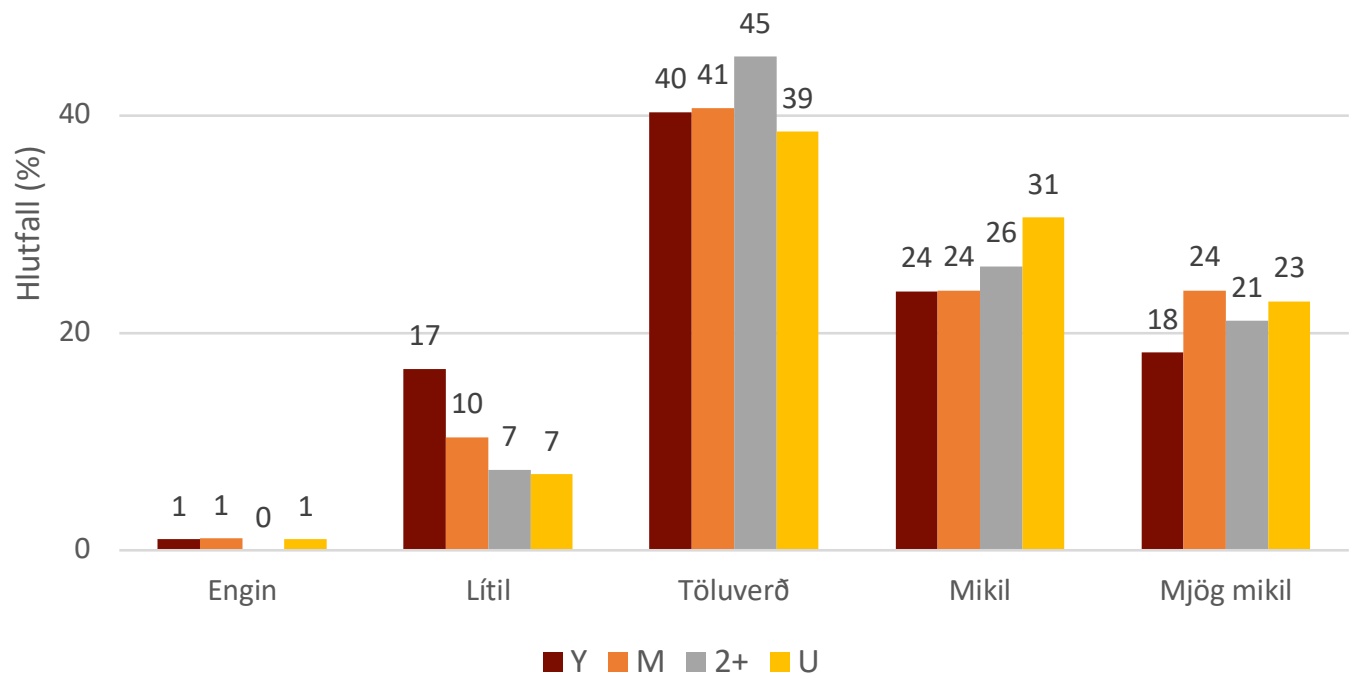

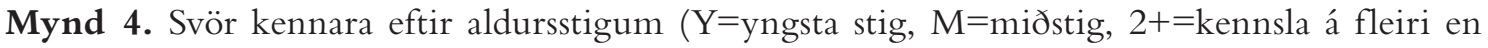
einu stigi, $U=$ unglingastig) við spurningunni: Hversu mikil eða lítil áhrif finnst pér breytingar vegna veirufaraldursins í vetur hafa haft á kennsluhætti í skólanum? 
Algengast var í öllum hópum að fólk teldi að um töluverð áhrif væri að ræða (39-45\%). Til viðbótar voru 42-54\% sem töldu um mikil eða mjög mikil áhrif að ræða. Unglingastigskennararnir voru líklegri en aðrir hópar til að svara að um mikil áhrif væri að ræða, 23\% peirra töldu áhrifin mjög mikil og 31\% mikil á meðan sambærileg hlutföll hjá yngsta stigs kennurum voru 18 og 24\% og hlutföll hjá miðstigskennurum og peim sem kenndu á tveimur eða fleiri stigum par á milli. Kennarar á yngsta stigi voru líklegri en aðrir til að telja að um lítil áhrif væri að ræða (17\% á móti $7-10 \%)$.

Pá var starfsfólk spurt hvort notkun pess á stafrænni tækni í sínu starfi hefði breyst vegna faraldursins. Svarhlutfall var um $81 \%$. Marktækur munur var á svörum eftir aldursstigum $\left(\chi^{2}(12, N\right.$ $=1253)=82,88, p<0,001)$. Svör má sjá á Mynd 5. Algengast var að kennarar teldu um töluverða breytingu að ræða, 32-37\% svöruðu pví til. Unglingastigskennarar og miðstigskennarar voru líklegri til að telja um miklar eða mjög miklar breytingar að ræða, 39\% unglingastigskennara töldu svo vera en 36\% miðstigskennara á hinn bóginn voru $24 \%$ peirra sem kenndu á fleiri en einu stigi og 17\% kennara á yngsta stigi sem töldu miklar breytingar hafa orðið á notkun peirra á stafrænni tækni. Síðarnefndu hóparnir voru líklegri til að telja breytingarnar engar eða litlar.

60

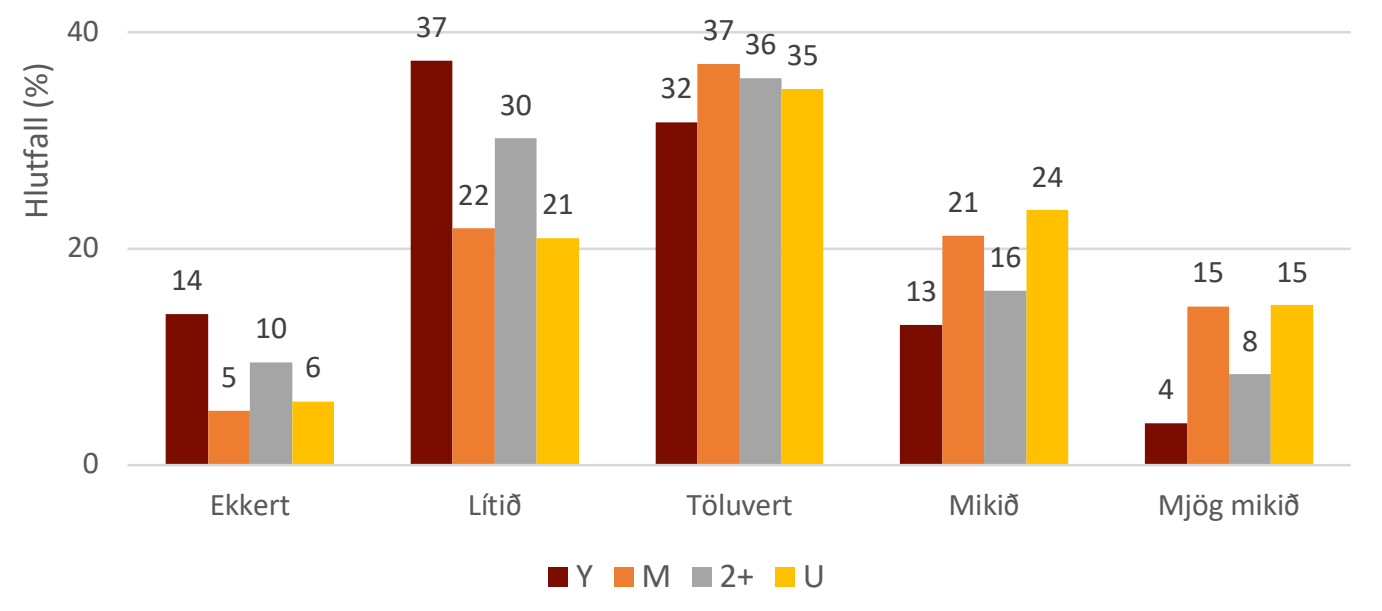

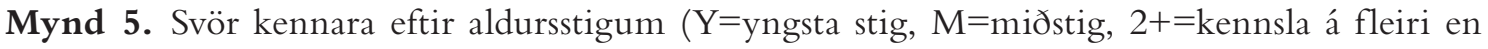
einu stigi, $\mathrm{U}=$ unglingastig) við spurningunni: Hefur notkun pín á stafrænni tækni í pínu starfi breyst vegna veirufaraldursins í vetur?

Kennarar svöruðu einnig spurningum um hvar kennsla peirra hefði aðallega farið fram áður en aðgerðir vegna faraldursins hófust (svarhlutfall 69\%) og svo hins vegar á meðan aðgerðum stóð (svarhlutfall 68\%). Svarmöguleikar voru í samræmi við flokkun sem notuð hefur verið víða til að meta umfang netnáms og blandaðs náms í skólum (t.d. Allen o.fl., 2016; Picciano og Seaman, 2007).

- Að öllu leyti á staðnum (100\%) og ekkert á netinu (0\%) (staðkennsla)

- Að mestu á staðnum (71-99\%) og einhverju leyti á netinu (1-29\%) (vefstudd kennsla)

- Að töluverðum hluta á staðnum (21-70\%) og töluverðum hluta á netinu (30-79\%) (blönduð kennsla, vendikennsla)

- Að litlu leyti á staðnum (1-20\%) og mestu leyti á netinu (80-99\%) (mest fjarkennsla)

- Að öllu leyti á netinu (100\%) (hrein fjarkennsla). 
Marktækur munur var á svörum eftir aldursstigum í báðum spurningum (í fyrri spurningu $\chi^{2}(12$, $N=1065)=87,65, p<0,001$; í síðari spurningu $\left.\chi^{2}(12, N=1054)=302,75, p<0,001\right)$.

Eins og sjá má í Töflu 2 varð mikil aukning í netkennslu hjä öllum hópum. Fyrir COVID var langalgengast að kennt væri að öllu leyti á staðnum og ekkert á netinu (91\% kennara á yngsta stigi, 77-78\% miðstigskennara og kennara á fleiri en einu stigi, og 64\% unglingastigskennara). Einnig var vefstudd kennsla (að mestu á staðnum en að einhverju leyti á netinu) nokkuð útbreidd fyrir COVID, ekki síst meðal unglingastigskennara (27\%). Um fimmtungur (20-21\%) miðstigskennara og peirra sem kenndu á fleiri en einu stigi sögðust hafa stundað vefkennslu en einungis 7\% kennara á yngsta stigi. Örfáir töldu sig hafa stundað meiri netkennslu og pá einkum unglingastigskennarar en 8\% peirra mátu kennslu sína fyrir COVID sem blandaða kennslu eða vendikennslu (að töluverðum hluta á staðnum og töluverðum á netinu).

Tafla 2. Hlutfall (\%) kennara eftir aldursstigum og svörum um hvar kennsla peirra hafi aðallega farið fram fyrir COVID-faraldurinn og í faraldrinum ( $\mathrm{Y}=$ yngsta stig, $\mathrm{M}=$ miðstig, 2+=kennsla á fleiri en einu stigi, $\mathrm{U}=$ unglingastig).

\begin{tabular}{|c|c|c|c|c|c|c|c|c|}
\hline \multirow[t]{2}{*}{ Svar } & \multicolumn{4}{|c|}{$\begin{array}{l}\text { Kennsla fyrir } \\
\text { COVID }\end{array}$} & \multicolumn{4}{|c|}{$\begin{array}{l}\text { Kennsla í } \\
\text { COVID }\end{array}$} \\
\hline & $\mathbf{Y}$ & $\mathbf{M}$ & $2+$ & $\mathbf{U}$ & $\mathbf{Y}$ & M & $2+$ & $\mathbf{U}$ \\
\hline Að öllu leyti á staðnum og ekkert á neti (staðkennsla) & 91 & 78 & 77 & 64 & 54 & 22 & 34 & 8 \\
\hline Að mestu á staðnum og einhverju leyti á neti (vefstudd kennsla) & 7 & 20 & 21 & 27 & 30 & 32 & 29 & 20 \\
\hline $\begin{array}{l}\text { Að töluverðum hluta á staðnum og töluverðum á neti (blönduð } \\
\text { kennsla, vendikennsla) }\end{array}$ & 1 & 2 & 1 & 8 & 10 & 26 & 13 & 20 \\
\hline Að litlu leyti á staðnum og mestu leyti á netinu (mest fjarkennsla) & 0 & 0 & 0 & 0 & 2 & 11 & 13 & 27 \\
\hline Að öllu leyti á netinu(hrein fjarkennsla) & 0 & 0 & 0 & 0 & 2 & 6 & 6 & 24 \\
\hline Á ekki við, ég fékkst ekki við kennslu & 1 & 0 & 1 & 0 & 2 & 2 & 6 & 2 \\
\hline
\end{tabular}

Kennsla í COVID færðist í miklum mæli á netið, ekki síst hjá unglingastigskennurunum, sjá Mynd 6. Í COVID stunduðu aðeins $8 \%$ peirra kennslu alfarið á staðnum, 20\% voru með vefstudda kennslu, 20\% blandaða, 27\% að litlu leyti á staðnum og að mestu leyti á neti en um fjórðungur (24\%) sagði kennsluna hafa verið að öllu leyti á netinu. Hjá öðrum hópum varð tilfærslan einnig töluverð frá hreinni staðkennslu.

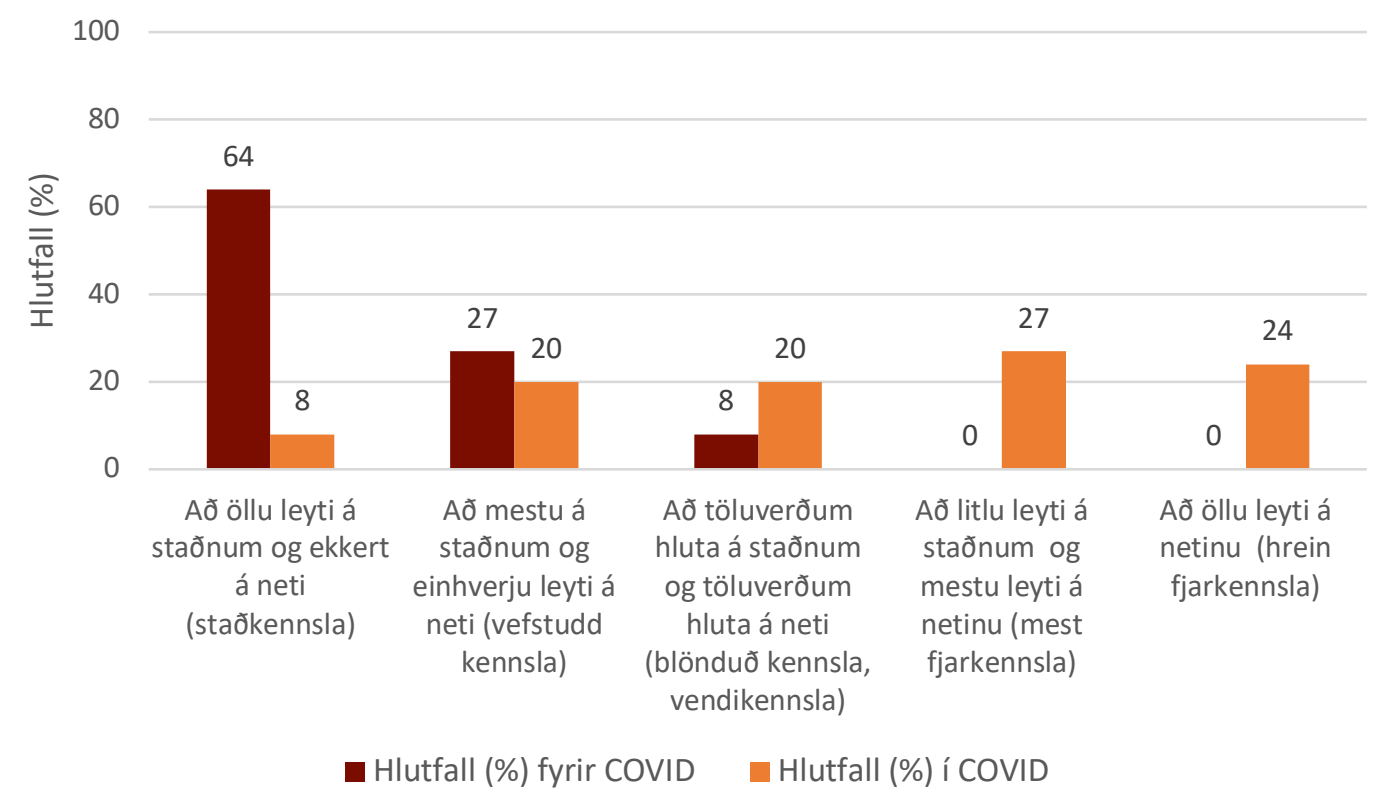

Mynd 6. Svör kennara á unglingastigi við spurningum um hvar kennsla peirra hafi aðallega farið fram áður en aðgerðir hófust og meðan á peim stóð. 
Jafnframt voru kennarar spurðir hvort ýmsir pættir (16 talsins) í peirra kennslu hefðu verið leystir að einhverju eða öllu leyti á netinu, annars vegar áður en aðgerðir vegna faraldursins hófust en hins vegar eftir að hann hófst. Marktækur munur var á svörum eftir aldursstigum í öllum páttum nema tveimur (leikræn tjáning, söngur og dans fyrir COVID; hátíðir og aðrir viðburðir í COVID). Yfirleitt gáfu unglingastigs- og miðstigskennarar til kynna meiri netnotkun en hinir hóparnir fyrir og í COVID en kennarar á yngsta stigi minnsta. Helstu undantekninguna má telja páttinn spil, prautir og leikir par sem kennarar á yngsta stigi og miðstigi gáfu til kynna meiri netnotkun en aðrir hópar. Litamerkt svör í Töflu 3 gefa til kynna umtalsvert hærra hlutfall svara eftir COVID; gult nokkuð (5-9\%), ljósgrænt töluvert (10-19\%), dökkgrænt mikið (20-29\%) og rautt nokkurn samdrátt (5-9\%). Hjá yngsta stiginu var einungis nokkur aukning á netnotkun varðandi einn fyrrnefndan pátt af 16 en lítil sem engin aukning 1 öđrum páttum. Hjá kennurum sem kenndu á tveimur stigum eða fleirum var nokkur aukning í fjórum páttum en töluverð 1 einum pætti. Hjá miðstiginu jókst netnotkun nokkuð í einum pætti en töluvert í 7 páttum. Hjá unglingastiginu varð nokkur aukning á netnotkun í einum pætti, töluvert í fimm tilvikum og mikil $(20+\%)$ í tveimur páttum.

Dættir par sem varð umtalsverð aukning á miðstigi, unglingastigi og hjá kennurum sem kenndu á tveimur eða fleiri stigum (2+-hópnum) voru sex (af 16). Umræður, spjall og samvera á netinu jukust mikið hjá unglingastigi (frá 9 í 37\%), og töluvert hjá miðstigi (frá 9 í 26\%) og 2+-hópi (frá 4 í 14\%). Dá varð mikil aukning hvað snertir kveikjur, hvatningu og aðhald hjá unglingastigi (frá 21 í 41\%), töluverð hjá miðstigi (frá 22 í 36\%) og nokkur hjá 2+-hópnum (frá 12 í 20\%). Einnig jókst netnotkun í leiðsögn og verklegri kennslu töluvert hjá miðstigs- (frá 10 í 23\%) og unglingastigskennurum (frá 10 í 22\%) og nokkuð hjá 2+-hópi (frá 4 í 10\%). Dað sama mátti segja um félagsleg samskipti nemenda (frá 9 í 22\% á miðstigi, 8 í 22\% á unglingastigi og 4 í 11\% hjá 2+). Dá var töluverð aukning á netnotkun í innlögnum, töflukennslu og sýnikennslu (frá 19 í 38\%) hjá unglingastiginu og nokkur hjá miðstigi og 2+-hópnum (frá 20 i 26\% og 9 í 16\%). Loks jókst netnotkun varðandi einstaklingsverkefni og vinnu að peim töluvert á miðstiginu (frá 31 í 41\%) og nokkuð á unglingastiginu (frá 45 í 50\%) og hjá 2+-hópnum (frá 20 í 26\%).

Dættir par sem varð nokkur eða töluverð aukning hjá tveimur hópum voru prír (af 16). Um var að ræða áctlanir og ábyrgð nemenda á eigin námi par sem nokkur aukning varð á yngsta stigi (frá 11 1́ 16\%) og töluverð á miðstigi (frá 31 1́ 44\%). Einnig var töluverð aukning í stuðningi við nemendur með sérparfir, hjá miðstigi (frá 18 í 27\%) og unglingastigi (frá 19 í 33\%). Í samvinnu kennara varð töluverð aukning á unglingastigi (frá 36 í 46\%) og nokkur á miðstigi (frá 38 í 47\%).

Í sjö páttum af 16 varð hins vegar lítil eða engin aukning í netnotkun og jafnvel svolítill samdráttur. Um var að ræða pættina hópverkefni og samvinna nemenda; verkefnaskil, námsmat og endurgjöf; skapandi starf og nýsköpun; leikræn tjáning, söng og dans; spil, prautir og leikir; hátíðir og aðrir viðburðir; og foreldrasamstarf.

Eins og fram kemur í Töflu 3 höfðu nokkrir pættir skólastarfs verið leystir að einhverju leyti á netinu hjá stórum hópum kennara, ekki síst á unglinga- og miðstigi, fyrir daga COVID. Par má nefna einstaklingsverkefni og vinnu að peim; kveikjur, hvatningu og aðhald; innlagnir, töflukennslu og sýnikennslu; ácotlanir og ábyrgð nemenda á eigin námi; samvinnu kennara; verkefnaskil, námsmat og endurgjöf; hópverkefni og samvinnu nemenda; og foreldrasamstarf. Reikna má með pví að kennarar hafi búið að pessari reynslu í COVID og ekki sást endilega aukning á netnotkun í öllum peim páttum. 
Tafla 3. Hlutfall (\%) kennara eftir aldursstigum og svörum við spurningum um hvort tilgreindir pættir í kennslu hefðu verið leystir á netinu fyrir COVID (FC) og í COVID (ÍC) ( $\mathrm{Y}=$ yngsta stig, $\mathrm{M}=$ miðstig, $2+=$ kennsla á fleiri en einu stigi, $\mathrm{U}=$ unglingastig).

\begin{tabular}{|c|c|c|c|c|c|c|c|c|}
\hline \multirow[t]{3}{*}{ Pættir í kennslu } & \multicolumn{8}{|c|}{ Hlutfall kennara $(\%)^{\star}$} \\
\hline & \multicolumn{2}{|c|}{$\mathrm{Y}$} & \multicolumn{2}{|c|}{ M } & \multicolumn{2}{|c|}{$2+$} & \multicolumn{2}{|c|}{$\mathrm{U}$} \\
\hline & FC & ÍC & FC & ÍC & FC & ÍC & FC & ÍC \\
\hline \multicolumn{9}{|l|}{ Umtalsverð aukning á premur stigum } \\
\hline Umræður, spjall og samvera & 6 & 9 & 9 & 26 & 4 & 14 & 9 & 37 \\
\hline Kveikjur, hvatning og aðhald & 13 & 17 & 22 & 36 & 12 & 20 & 21 & 41 \\
\hline Leiðsögn og verkleg kennsla & 4 & 6 & 10 & 23 & 4 & 10 & 10 & 22 \\
\hline Félagsleg samskipti nemenda & 3 & 3 & 9 & 22 & 4 & 11 & 8 & 22 \\
\hline Innlagnir, töflukennsla og sýnikennsla & 11 & 9 & 20 & 26 & 9 & 16 & 19 & 38 \\
\hline Einstaklingsverkefni og vinna að peim & 13 & 15 & 31 & 41 & 20 & 26 & 45 & 50 \\
\hline \multicolumn{9}{|l|}{ Umtalsverð aukning á tveimur stigum } \\
\hline Áætlanir og ábyrgð nemenda á eigin námi & 11 & 16 & 31 & 44 & 22 & 25 & 50 & 53 \\
\hline Stuðningur við nemendur með sérparfir & 10 & 12 & 18 & 27 & 10 & 12 & 19 & 33 \\
\hline Samvinna kennara & 33 & 36 & 38 & 47 & 28 & 31 & 36 & 46 \\
\hline \multicolumn{9}{|l|}{ Lítil sem engin aukning eða samdráttur } \\
\hline Verkefnaskil, námsmat og endurgjöf & 13 & 15 & 40 & 45 & 27 & 26 & 53 & 55 \\
\hline Hópverkefni og samvinna nemenda & 9 & 5 & 26 & 22 & 16 & 14 & 36 & 29 \\
\hline Skapandi starf og nýsköpun & 6 & 3 & 10 & 14 & 6 & 6 & 12 & 8 \\
\hline Leikræn tjáning, söngur og dans & 5 & 4 & 6 & 10 & 3 & 5 & 4 & 4 \\
\hline Spil, prautir og leikir & 16 & 14 & 18 & 22 & 10 & 11 & 10 & 13 \\
\hline Hátíðir og aðrir viðburðir & 5 & 2 & 6 & 3 & 1 & 1 & 2 & 2 \\
\hline Foreldrasamstarf & 37 & 36 & 44 & 42 & 22 & 20 & 32 & 32 \\
\hline
\end{tabular}

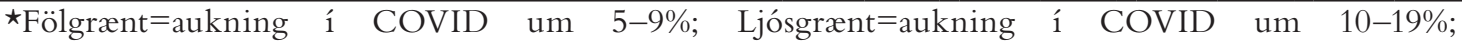

Grænt=aukning í COVID um 20-29\%; Ljósrautt=samdráttur í COVID um 5-9\%.

Spurt var um átta leiðir til samskipta við nemendur eftir að skólastarf var takmarkað, hvort viðkomandi leið hefði verið nýtt (aldrei, sjaldnar en ádur, jafn oft og ádur eða oftar en áður). Fram kom pegar á heildina var litið að tæpur priðjungur (32\%) sagðist nota netfunda- og myndsamtalakerfi (á borð við Google Meet, Skype, Zoom eða Teams) oftar en áður. Um 31\% sagðist nota tölvupóst oftar en áđur og 24\% námsumsjónar- og kennslukerfi (á borð við Google Classroom, MySchool eða Moodle). Dá voru um 17\% sem sögðust nota talsíma meira, 15\% skráningar- og utanumhaldskerfi (á borð við Mentor, Námfús eða Seesaw), 10\% samfélagsmiðla (á borð við Facebook, Messenger, Snapchat, Instagram, TikTok eða Twitter). Nokkrir sögðust einnig nota oftar smáskilaboð (6\%) eða töskupóst (3\%).

Marktækur munur var á svörum eftir aldursstigum í öllum samskiptaleiðum. Svör má sjá á Mynd 7. Töluvert hærra hlutfall unglingastigs- og miðstigskennara heldur en yngsta stigs og 2+-hópanna voru að nýta oftar netfundi (54 og 38\% vs. 25 og 15\%)2 námsumsjónarkerfi (44 og $37 \%$ vs. 18 og 6\%) $)^{3}$, tölvupóst (34 og 35\% vs. 25 og 30\%) og skráningarkerfi (19 og 18\% vs. 11 og $12 \%)^{5}$. Pá voru unglingastigskennarar að nýta sér oftar en aðrir hópar talsíma (22\% vs. $\left.12-17 \%\right)^{6}$, samfélagsmiðla (14\% vs. $7-10 \%)^{7}$ og smáskilaboð (11\% vs. 3-6\%) ${ }^{8}$. Á hinn bóginn virtist örlítið hærra hlutfall yngsta stigs (5\%) kennara hafa nýtt töskupóst í meiri mæli en áður í samanburði við hina hópana $(1-3 \%)^{9}$. Stór hluti allra hópanna sagðist aldrei hafa nýtt töskupóst í faraldrinum (34\% á yngsta stigi, $42 \%$ á miðstigi, 30\% í 2+-hópnum og 50\% á unglingastigi).

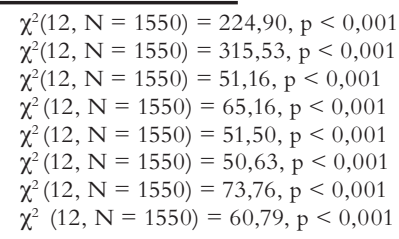


Netfunda- og myndsamtalakerfi á borð við Google Meet, Skype, Zoom eđa Teams

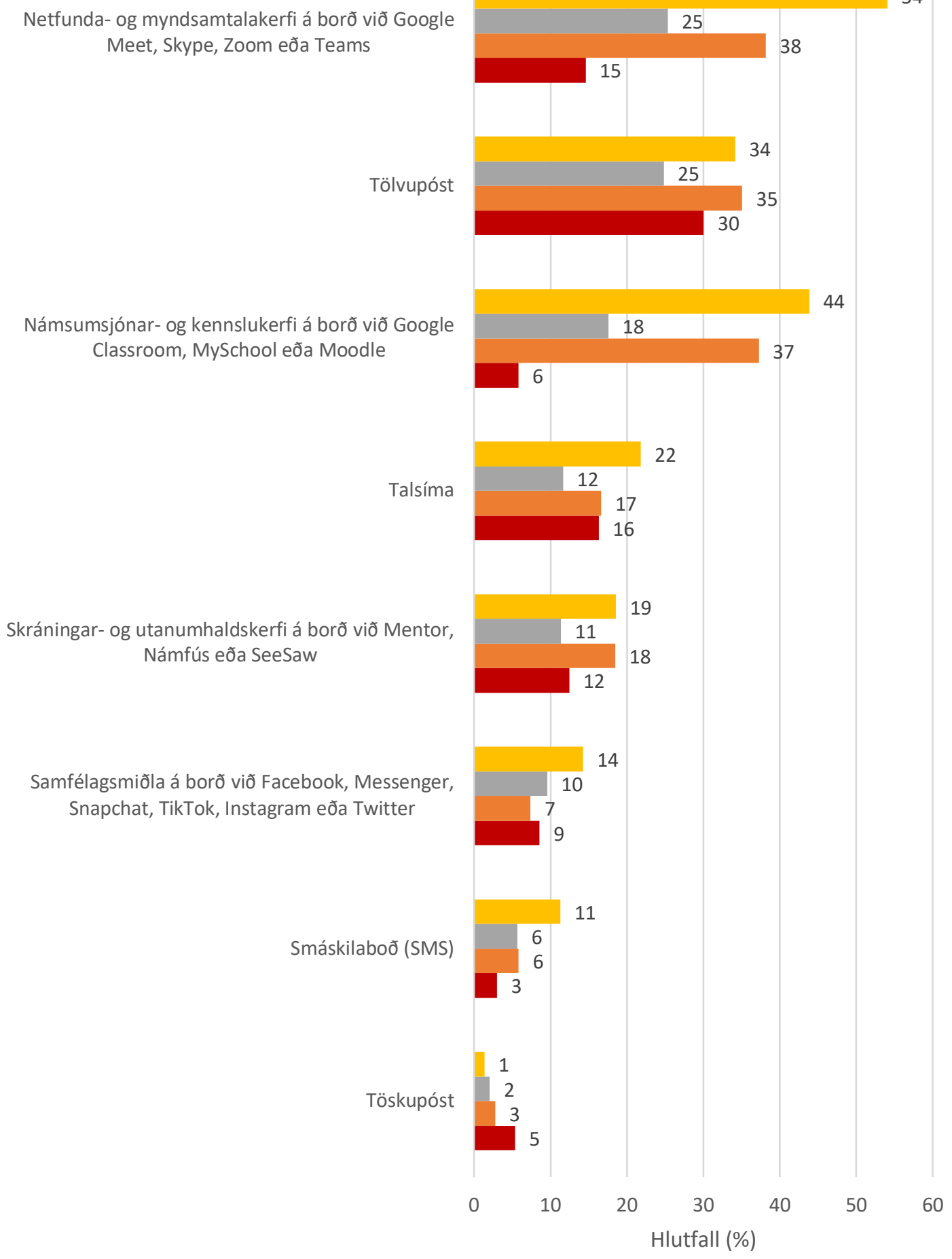

38

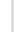

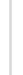

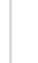

Námsumsjónar- og kennslukerfi á borđ við Google Classroom, MySchool eða Moodle

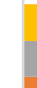

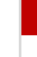

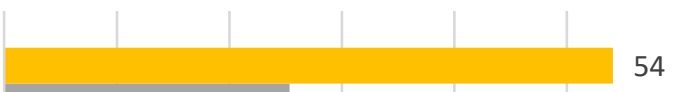

54 


\section{Skapandi starf, miðlun og samskipti með hjálp stafrænnar tækni}

Spurt var um skapandi starf með hjálp stafrænnar tækni í skólanum - hvort pað hefði aukist eða dregist saman í faraldrinum. Svarhlutfall var 68\% og svör má sjá á Mynd 8. Dar kemur fram að stór hluti taldi hvorki um aukningu né samdrátt að ræða (27-35\%). Annars skiptist fólk í tvö horn hvað petta varðar og par töldu fleiri að um aukningu hefði verið að ræða en samdrátt á skapandi starfi. Munur eftir aldursstigum var marktækur $\left(\chi^{2}(15, N=1049)=27,10, p=0,028\right)$.

Aðeins algengara var að mið- og unglingastigskennarar teldu að hefði orðið aukning á skapandi starfi, 11 og 12\% peirra töldu um mikla aukningu að ræða og 28 og 25\% nokkra (samtals 39 og 36\%). Á hinn bóginn töldu 6\% yngsta stigs hópsins og 8\% 2+-hópsins um mikla aukningu að ræða og 23\% beggja hópa nokkra (samtals 29-31\%). Um 6-7\% töldu skapandi starf hafa dregist nokkuð saman en 7-10\% mikið (samtals 13-16\%).

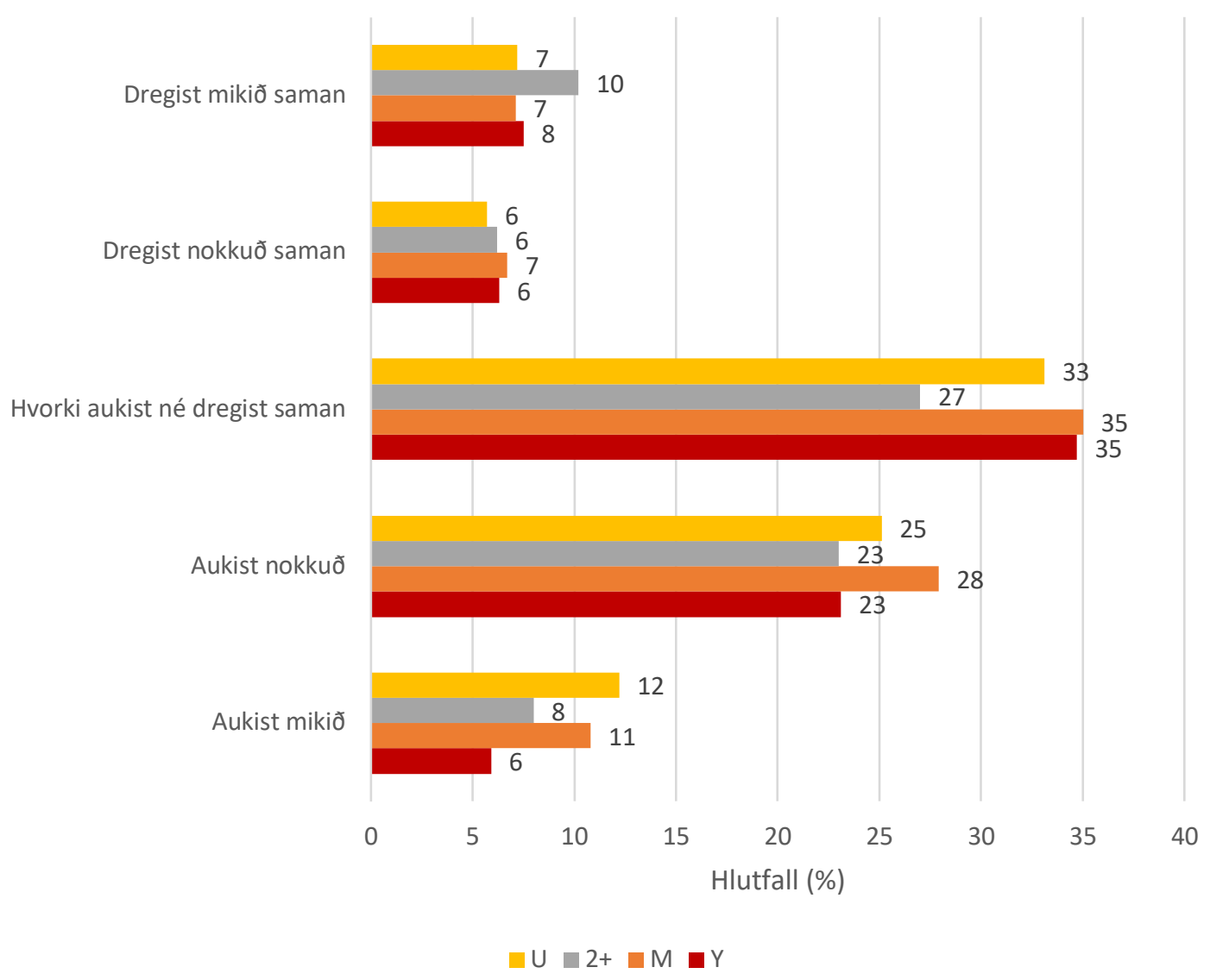

Mynd 8. Svör kennara eftir aldursstigum ( $Y=$ yngsta stig, $M=$ miðstig, $2+=$ kennsla á fleiri en einu stigi, $U=$ unglingastig) við spurningunni: Hefur skapandi starf með hjálp stafrænnar tækni í skólanum aukist eða dregist saman í faraldrinum?

Dessu fylgdi að svarendur voru beðnir að lýsa pví hvernig skapandi starf með hjálp stafrænnar tækni hefði helst aukist eða dregist saman. Dví kalli svöruðu 202 kennarar og 21 leiðbeinandi. Flestir $(115+14)$ höfðu peir sagt skapandi starf hafa aukist en allmargir $(56+3)$ pað hafa dregist saman og nokkrir $(35+3)$ аð pað hefði ekki breyst eða að pað gætu peir ekki metið. Hér verður pví lýst sem fram kom í pessum svörum um verkefnavinnu nemenda, notkun á stafrænum og veflægum námsgögnum og tólum, námsefnisgerð kennara og samstarf kennara, pátttöku foreldra í verkefnavinnu og hvernig sviptingar í skólastarfi póttu hafa áhrif á skapandi starf með stafrænum miðlum, bæði í skólanum og á heimilum við heimanám og fjarnám. Einnig er dregið fram að oft reyndist erfiðleikum bundið að nýta stafrænan búnað í skólanum til skapandi starfs á tímum COVID. 


\section{Verkefnavinna nemenda}

Verkefnavinna nemenda var sá páttur sem langoftast var nefndur par sem lýst var aukningu á skapandi starfi (24+6) með hjálp stafrænnar tækni. Fram kom ásamt fleiri kostum að tækninni fylgdu möguleikar á fleiri og fjölbreyttari verkefnum, að úrlausnir gátu verið með margvíslegu sniði (ritvinnsluskjöl, hljóðskrár, myndir, myndbönd) og verkefnaskil á stafrænu formi. Fleiri verkefni voru leyst með myndskeiðum eða stuttmyndum og meira var unnið með samsetningu á tónlist, texta og myndum. Einnig gáfust nýir möguleikar við efnisöflun og upplýsingaleit, svo sem að nýta vefi og kennslumyndbönd og finna til efnivið og hugmyndir á netinu. Ennfremur var nefnt að pegar nemendur fengjust við stafræn og veflæg verkefni gætu peir sinnt peim og glímt við skapandi vinnu á öllum tímum dags og nætur. Nokkrir nefndu að fjölskyldan hefði tekið pátt í skapandi verkefnavinnu nemenda:

Við hvöttum nemendur til að búa til stutt leikrit og peir nemendur sem voru heima fengu að vinna verkefnið með fjölskyldunni. Deir nemendur sem voru heima og gerðu stutt leikrit, leyfðu sumir að sýna leikritið í tíma við mikla kátínu. Nemendur unnu leikritið með fjölskyldunni sinni.

Баð töldu hins vegar ekki allir sem svöruðu að skapandi starf með stafrænni tækni hefði aukist í verkefnavinnu nemenda. Nokkrir nefndu par pætti sem hömluðu skapandi starfi, svo sem lítið aðgengi margra nemenda að stafrænum tækjum heima fyrir eða skort á nauðsynlegri handleiðslu:

Erfitt að bjóða upp á opin verkefni pví pau parfnast meiri leiðsagnar. Leitast var við að hafa verkefni einföld og auðskiljanleg til að foreldrar gætu leiðbeint af öryggi án pess að verja of miklum tíma í að setja sig inn í verkefnin.

Sérstaklega virðist pað hafa hamlað tækninotkun hve erfitt og stundum ómögulegt var víða að nota stafræn verkfæri og búnað í skólanum sjálfum vegna sóttvarnareglna og koma við hópverkefnum vegna fjarlægðarmarka sem sett voru í sóttvarnaskyni. Svör sýna að víða var í skólum brugðist við faraldrinum með neyðarráðstöfunum pannig að kjarnagreinar og bóklegar greinar voru settar í forgang en greinasvið og viðfangsefni sem nýttu mest stafræna tækni á skapandi hátt féllu niður.

\section{Námsefni og námstól}

Í faraldrinum batnaði aðgengi að ýmiss konar vefefni og öppum til skólanota og margar námsveitur, innlendar sem erlendar, opnuðu tímabundinn aðgang að efni fyrir skólanemendur. Í flestum ríkjum settu skólayfirvöld upp sérstök vefsetur og hjálparsíður til að bregðast við ástandinu og auðvelda kennurum aðgang að efni. Á Íslandi setti Menntamálastofnun upp vefsetur og einnig ýmis sveitarfélög. Af svörum má ráđa að íslenskir kennarar hafa töluvert nýtt sér ýmsar vefsíður og kennslumyndir á pessum tíma. Einnig nýttu kennarar sér ýmiss konar öpp, forrit og veflausnir pann tíma sem skólastarf var takmarkað. Minnst var meðal annars á ýmis Google-verkfæri og Google Classroom, en einnig Seesaw, Flipgrid, Book Creator, iMovie, Kami, Kahoot, Quizlet, Quizizz, Zoom, Meet og QR-kóða. Af mörgum svörum má líka ráđa að nemendur notuðu spjaldtölvur enn meira en ádur:

Hef lagt áherslu á notkun spjaldtölva í kennslu. Nemendur hafa kynnt sér fjölbreytt forrit, unnið í Seesaw og notað myndavélar í útiveru.

Nú fer kennsla að mestu leyti fram í Classroom, til dæmis með videóinnlögn og fyrirspurnum par í gegn eða á Meet fyrir pá sem pað kjósa.Verkefnaskil eru meiri og markvissari og fara alveg fram í Classroom.

\section{Námsefnisgerd kennara og samstarf kennara}

Svo virðist sem margir kennarar hafi tileinkað sér ýmsar nýjungar á pessum tíma, lært nýjar aðferðir og lært á ný verkfæri, ekki síst til að takast á við að hluti nemenda var heima og hluti í skóla. Sumir kennarar lærðu að gera gagnvirkar skjákynningar eða finna námsefni á netinu og leituðu 
að og nýttu sér öpp sem ýta undir skapandi starf. Sumir kennarar stigu skref á átt til vendináms eða staðnáms með stuðningi á netinu, peir lærðu að taka upp kennslu sína og útbjuggu ýmiss konar stafrænt efni fyrir nemendur. Nokkrir nefndu aukna samvinnu kennara við verkefnagerð og hugmyndavinnu vegna fjarkennslu og að kennarar væru duglegir að deila hugmyndum sín á milli:

Ég hef búið til stafrænt kennsluefni á neti út af faraldrinum, sem hefur haldið utan um verkefni, rannsókn, miðlun og námsmat. Dannig hef ég sem kennari lært bæði að gera gagnvirkar glærukynningar og vefsíður á pessum tíma.

Stuðningur foreldra

Nokkrir $(5+2)$ nefndu að stuðningur foreldra og aðstoð við verkefnavinnu hefðu skipt miklu máli. Með foreldrastuðningi hefði tæknikunnátta nemenda aukist og foreldrar tekið pátt 1 að meta og vinna verkefni. Í sumum tilvikum voru verkefni og leiðbeiningar send heim par sem foreldrar aðstoðuðu við útfærslu og skapandi starf:

Nemendur hafa unnið skapandi verkefni heima pá daga sem peir eru ekki í skólanum og pá er gjarnan markmiðið að draga fjölskyldumeðlimi inn í verkefnin.

Skammur tími í skólanum fyrir skapandi starf.Verkefni send rafrænt og pau gera eitthvað skapandi heima með foreldrum sínum.

Dannig virðist námsumhverfi margra nemenda sem voru við heimanám eða nutu fjarkennslu í faraldrinum hafa batnað hvað snertir skapandi starf með stafrænni tækni utan skólans, peir höfðu aðgang að búnaði, fengu leiðsögn kennara og nutu aðstoðar frá foreldrum. Um leið dróst skapandi starf saman í skólanum sjálfum vegna sóttvarna og neyðarráđstafana.

Áhersla á kjarnagreinar á kostnað list- og verkgreina

Í sumum tilvikum töldu kennarar og leiðbeinendur að í skólastarfi á COVID-tíma hefði skapandi starf (11+3) með stafrænni tækni dregist saman og skólastarf orðið einhæfara, verkefnin einfölduð og orðið textamiðaðri með ritun, eyðufyllingar og hlustun í forgrunni, kennarar notuðu alltaf sömu forritin og gerðu lítið af pví að prófa eitthvað nýtt. Pá kom fram í ýmsum svörum (11) að list- og verkgreinar voru felldar niður, verkgreinastofum verið lokað og pað hafi hamlað skapandi starfi. List- og verkgreinakennarar voru settir í önnur störf og skipulag virðist víða hafa miðast mest við bóklegar greinar.

\section{Minna aðgengi að takjum og erfiðleikar við hópstarf i skólanum}

Í mörgum svörum mátti lesa að kennarar og leiðbeinendur teldu skapandi starf hafa aukist en einnig voru margir sem töldu að skapandi starf hefði dregist saman og pá vegna reglna um sótthreinsun, fjarlægð milli nemenda og fjölda í rýmum. Svigrúm til að undirbúa skapandi starf með hjálp tækninnar gat líka verið lítið:

Gríðarlegt álag var á starfsfólki skólans á meðan á faraldrinum stóð. Börn mættu í skólann alla daga og voru inni í kennslustofu allan daginn með einum frímínútum. Ekki gafst tími fyrir mikinn undirbúning af nokkru tagi. Dagurinn var spilaður af [fingrum] fram dag frá degi sem jók álag starfsfólks til muna. Pví var ekkert pláss fyrir skapandi starf í bekknum með hjálp stafrænna tækja.

Langflestir af peim sem nefndu að skapandi starf hefði minnkað (19+3) töldu að pað stafaði af skorti á aðgengi að tölvum og búnaði í skólanum og erfiðleikum við að nota búnað og vinna saman í hópum vegna COVID:

Skapandi starf í stafrænni tækni hefur yfirleitt verið unnið í hópum hér í skólanum og með tækjum skólans. Öll hópavinna í skólanum hefur dregist saman til að koma í veg fyrir möguleika á smiti. Dessi vinna hefur ekki færst heim enda eru nemendur með töluverða viðveru í skólabyggingunni og ekki með tæki til að vinna verkefnin heima. 
Dar sem pláss í okkar skóla er af skornum skammti og við purfum að gæta að pví að blanda hópum ekki saman getur verið snúið að bjóða upp á aðstæður fyrir skapandi starf. Skapandi starf parf nefnilega töluvert pláss, pví oft parf grænskjái, dansgólf og ekki síður næði hópa sem vinna saman.

Víða pótti nær ómögulegt að nýta tölvubúnað í skólanum vegna smithættu og reglna um sótthreinsun og sumt skapandi starf, sem hefð var fyrir í skólanum, stórar sýningar og fleira pess háttar, var einfaldlega fellt niður.

\section{Áhrif til framtíðar}

Kennarar voru spurðir hvort peir teldu að fordæmalausar aðstæður vegna COVID-faraldursins myndu breyta kennsluháttum í skólanum peirra til frambúðar. Svarhlutfall var 83\%. Marktækur munur var á svörum eftir aldursstigum $\left(\chi^{2}(12, N=1291)=47,64, p<0,001\right)$. Meirihluti kennara á öllum aldursstigum taldi pað öruggt eða sennilegt en kennarar á yngsta stigi voru heldur ólíklegri til að líta svo á. Svör má sjá á Mynd 9. Um 12\% kennara á yngsta stigi töldu öruggt að kennsluhættir breyttust og 39\% аð pað væri sennilegt (samtals 51\%). Hins vegar töldu 20\% miðstigskennara og 21\% unglingastigskennara pað öruggt en 52\% miðstigskennara og 49\% unglingastigskennara sennilegt (70-72\% samtals). Heldur færri eða 18\% í 2+-hópi töldu breytingar á kennsluháttum öruggar en $47 \%$ sennilegar (samtals 65\%). Á hinum kantinum töldu 20\% kennara á yngsta stigi litlar sem engar líkur á breyttum kennsluháttum vegna COVID en pað hlutfall var 10-14\% hjá öðrum hópum.

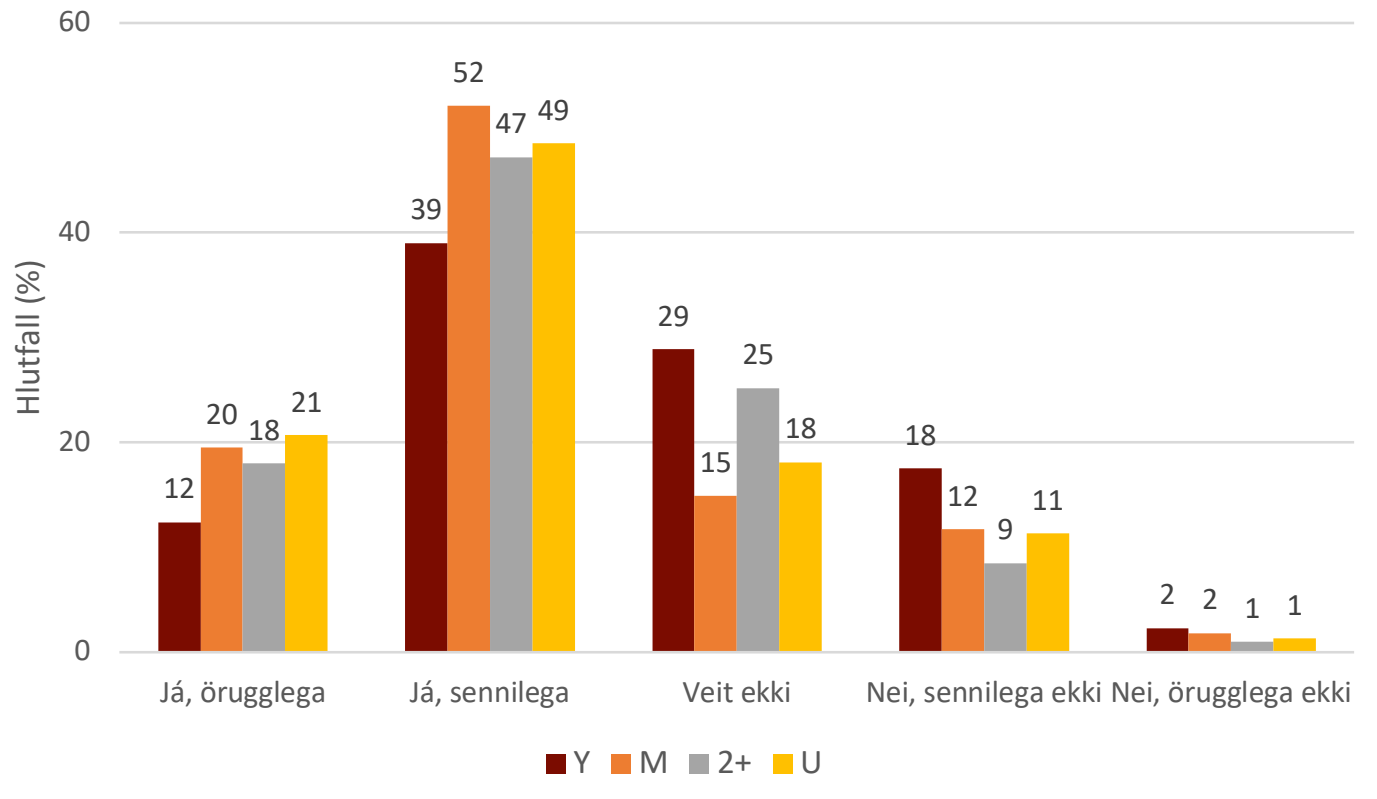

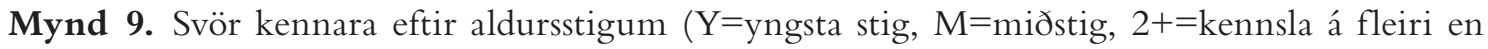
einu stigi, $U=$ unglingastig) við spurningunni: Telur pú að pessar fordæmalausu aðstæður vegna COVID-faraldursins muni breyta kennsluháttum í skólanum pínum til frambúðar?

Svarendur voru beðnir að merkja við fimm atriði af 10 sem peir væru sammála um að væru mikilvæg til að pess að skólinn gæti búið sig betur undir framtíðina. Marktækur munur eftir aldursstigum var á svörunum ef frá eru taldir liðirnir að auka faglega leiðsögn og faglega rádg jöf innanhúss; að prýsta á um aukna miðlagga pjónustu við skóla og annað. Að öðru leyti reyndust unglingastigs- og miðstigskennarar frekar sammála um mikilvægi en kennarar í öđrum hópum. Á Mynd 10 má sjá svörunum raðað eftir mikilvægi að dómi kennara. 
Búa kennara undir aukna net- og fjarkennslu

Huga að nemendahópum međ veikan félagslegan bakgrunn

Huga að nemendahópum með erlendan bakgrunn

Tryggja snjalltæki eđa fartölvur fyrir alla nemendur

Bjóđa upp á fleiri námsbækur og námsgögn á neti

Vinna að eđa kalla eftir námskeiðum og námspökkum sem kennarar geta notað með...

Auka faglega leiđsögn og faglega ráđgjöf innanhúss

próa kennslu list- og verkgreina með stuðningi af neti

prýsta á um aukna miðlæga pjónustu við skóla

Annað
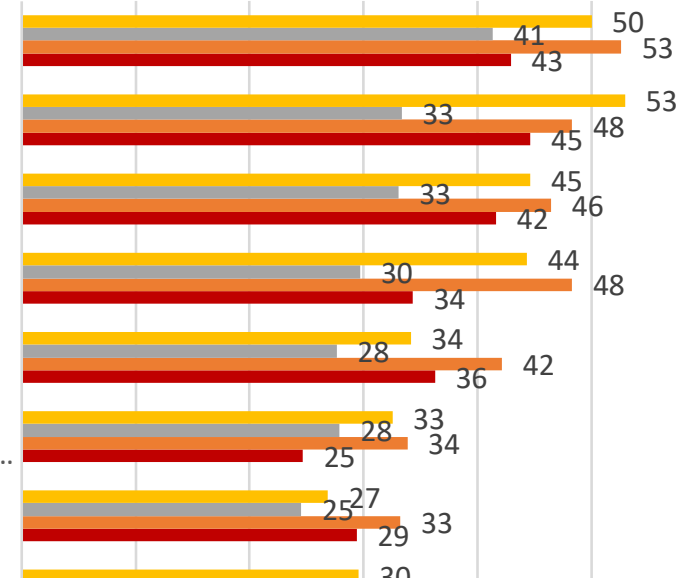

33
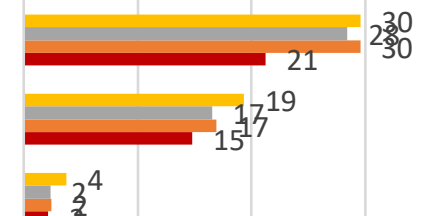

$$
20
$$

30

50

60

Hlutfall (\%)

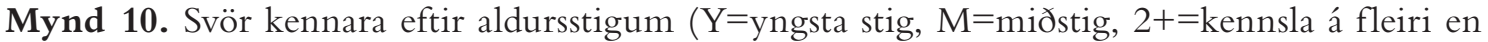
einu stigi, $\mathrm{U}=$ unglingastig) við spurningunni: Telur pú að skólinn purfi að búa sig betur undir framtíðina og pá hvernig? Merktu við atriði sem pú telur mikilvæg, mest fimm atriði.

Pau fimm atriði sem fólk taldi einna mikilvægust voru í fyrsta lagi að búa kennarahópinn undir aukna net- og fjarkennslu. Yfir helmingur unglingastigs- og miðstigskennara taldi pað mikilvægt (50-53\%) og 41-43\% kennara í 2+-hópi og á yngsta stigi. Pá var talið mikilvægt að huga að nemendahópum mеð veikan félagslegan bakgrunn (33-53\%) og með erlendan bakgrunn (33-46\%). Ennfremur voru margir sammála um mikilvægi pess að tryggja snjalltaki eða fartölvur fyrir alla nemendur (30-48\%) og bjóða upp á fleiri námsbrekur og námsgögn á netinu (28-42\%).

Færri merktu við að vinna eða kalla eftir námskeiðum og námspökkum sem kennarar getu notað með nemendum sínum pvert á skóla (25-34\%); próa kennslu list- og verkgreina með stuðningi af netinu (28-30\%); prýsta á um aukna miðlaga pjónustu við skóla (15-19\%) eða annað ótilgreint (2-4\%).

Kennarar voru einnig spurðir hversu mikinn eða lítinn áhuga peir hefðu á að sækja einingabært nám á háskólastigi um hagnýtar leiðir í notkun stafrænnar tækni í námi og kennslu. Svarhlutfall var 63\%. Marktækur munur var á svörum eftir aldursstigi $\left(\chi^{2}(12, N=981)=35,60, p<0,001\right)$. Svör má sjá á Mynd 11. 


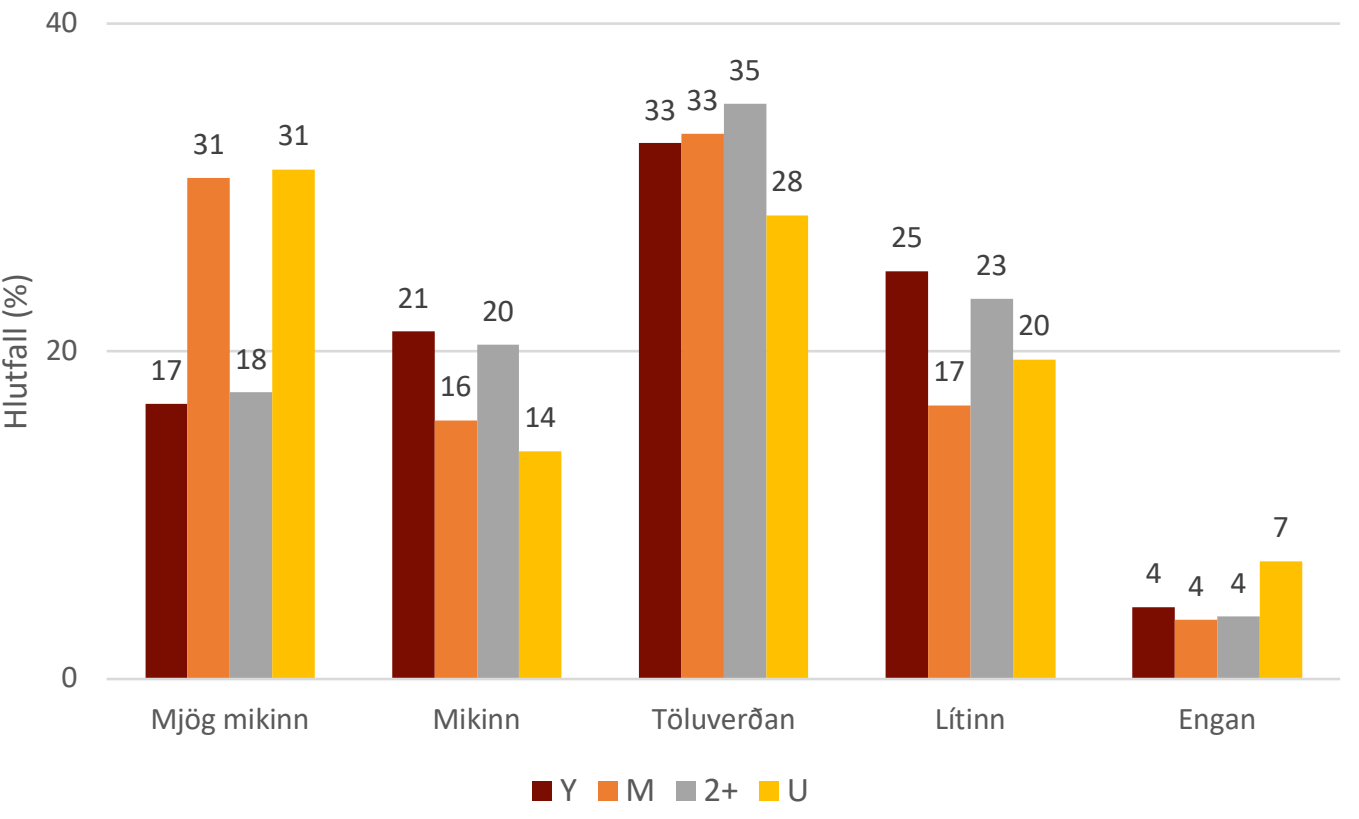

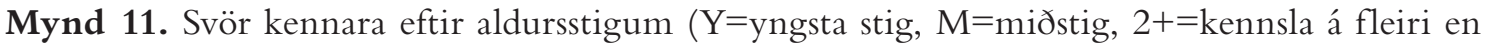
einu stigi, U=unglingastig) við spurningunni: Hversu mikinn eða lítinn áhuga hefur pú á að sækja einingabært nám um hagnýtar leiðir í notkun stafrænnar tækni í námi og kennslu?

31\% unglingastigs- og miðstigskennara höfðu mjög mikinn áhuga en 17 og 18\% kennara í 2+hópi og á yngsta stigi. 14-21\% í öllum hópum gáfu til kynna mikinn áhuga. Rúmur fjórðungur til rúmur priðjungur svarenda (28-35\%) höfðu svo töluverðan áhuga á slíku námi. Á hinn bóginn var um fjórðungur (23 og 25\%) kennara í 2+-hópi og á yngsta stigi sem hafði lítinn áhuga en 17 og 20\% miðstigs- og unglingastigskennaranna. Um 4-7\% gáfu til kynna engan áhuga.

\section{Samantekt og umræða}

Í pessum lokakafla verða niðurstöður reifaðar í stuttu máli með pað fyrir augum að svara rannsóknarspurningum sem lagt var upp með hér að framan. Dá verður öðrum præði og í lokin bent á áskoranir og tækifæri í peirri stöðu sem rannsóknin lýsir.

\section{Skólar og heimili misvel búin undir breytta kennsluhætti}

Svör við fjölvalsspurningum í könnun okkar benda til pess að töluverður meirihluti peirra sem annast kennslu við grunnskóla telji skólana vel búna stafrænum verkfærum og starfsliðið fremur vel búið undir að takast á við aukin tölvusamskipti og fjarkennslu. Dá töldu flestir að aðgengi nemenda að tækni heima fyrir dygði vel til samskipta eða fjarnáms í faraldrinum. Hluti svarenda var neikvæðari hvað pessi atriði snerti sem minnir á að heimili og skólar eru misjafnlega búin tækjakosti og bendir til að ekki sé allt starfsfólk jafn vel í stakk búið til að takast á við breytingar. Athygli vekur að afstaða kennara á yngri aldursstigum er önnur en kennara á eldri stigum og endurspeglar að einhverju marki aðra stöðu kennara yngri nemenda gagnvart tækninni og leiðum til að beita henni í námi og kennslu en kennara á eldri stigum. Pá benda niðurstöður til að yngri nemendur búi margir við síðra aðgengi að tækjakosti heima fyrir og á vettvangi skóla en peir eldri. Svör við opinni spurningu gáfu svo til kynna að sóttvarnaaðgerðir skóla hefðu víða teppt aðgengi að búnaði og spyrja má hvort ekki megi sóttverja hann eða finna leiðir til að nýta hann án teljandi smithættu. Upp úr stendur að kennarar, einkum á eldri aldursstigum, líta margir svo á að pekking og færni við beitingu stafrænnar tækni í skólastarfinu hafi batnað til muna og pví fylgi að líkindum breyttir kennsluhættir til lengri tíma. 


\section{Breyttir kennsluhættir kalla á hópvinnu og verkefni með nýju sniði}

Niðurstöðurnar endurspegla mikla breytingu á kennsluháttum og nýtingu stafrænnar tækni margra kennara í faraldrinum. Flestir kennarar nýttu meira en ádur stafrænar samskiptalausnir, netfundi og tölvupóst. Gripið var til fjölda stafrænna verkfæra, auk námsumsjónar- og kennslukerfa sem hafa verið tekin upp við marga skóla. Blandaðri kennslu og netkennslu var ekki síst beitt við spjall og samræður eða umræður um valið efni en tók líka til fleiri pátta í skólastarfinu, mest á unglingastigi en einnig á öðrum aldursstigum. Nokkuð dró úr samvinnu nemenda og hópverkefnum en slíka vinnu kann að vera erfitt að skipuleggja pegar nemendur eru hver heima hjá sér og kennarar og nemendur óvanir að nýta stafrænar samvinnulausnir. Verkefni parf líka að leggja fyrir á annan hátt pegar kennarar eru ekki á staðnum til að vaka yfir og halda utan um vinnu nemenda. Undirbúa parf kennara betur til verka. Pá kom í ljós að stuðningur foreldra reyndist mikilvægur en er ekki til staðar á öllum heimilum og parf að taka mið af pví við útfærslu náms og kennslu.

\section{Stafræn tækifæri og skertir möguleikar til sköpunar}

Af svörum má ráđa að sumir nemendur fengu tækifæri til sköpunar með stafrænum verkfærum í faraldrinum. Aftur á móti veldur áhyggjum að kennsla á tilteknum greinasviðum var að verulegu eða öllu leyti felld niður. Par er ekki síst um að ræða list- og verkgreinar en einnig upplýsinga- og tæknimennt. Benda má á að hún ætti mögulega meira erindi en margt annað á farsóttartímum og gæti pjónað pví hlutverki að efla tölvunotkun og tengsl heima fyrir undir peim kringumstæðum. Jafnframt er ljóst að huga parf betur að möguleikum kennara til að beita blandaðri kennslu og fjarkennslu í list- og verkgreinum með hjálp stafrænnar tækni um leið og beint yrði aukinni athygli að stafrænum viðfangsefnum á sviðum peirra greina til að fást við pegar hefðbundin verkfæri eða efniviður eru ekki tiltæk. Slíkar áherslur myndu ekki aðeins auðvelda framkvæmd skólastarfs á farsóttartímum, styðja greinakennslu á pessum sviðum, færa kennurum aukin tækifæri í kennslu og auka möguleika nemenda til sjálfstæðra vinnubragða heldur einnig kallast á við pá tæknipróun sem sett hefur mark sitt á viðkomandi greinar í öllu athafnalífi.

\section{Breytingar til frambúðar kalla á bjargir, stuðning, samhjálp og menntun}

Meirihluti kennara á öllum aldursstigum taldi að COVID-faraldurinn myndi breyta kennsluháttum í skólum peirra til frambúðar og að skólinn gæti búið sig betur sig undir framtíðina og pá einkum búið kennarahópinn betur undir blandaða kennslu og fjarkennslu. Einnig pótti mikilvægt að huga að nemendum með veikan félagslegan bakgrunn eða erlendan bakgrunn og tryggja snjalltæki eða fartölvur fyrir alla nemendur. Allmargir töldu mikilvægt að bjóða upp á fleiri námsbækur og námsgögn á netinu eða sáu tækifæri á námskeiðum og námspökkum pvert á skóla. Margir stjórnendur lögðu áherslu á pörf fyrir faglega ráđgjöf og leiðsögn innanhúss, svo og að próa kennslu list- og verkgreina með stuðningi af netinu. Loks kom í ljós verulegur áhugi á að sækja einingabært nám á háskólastigi um hagnýtar leiðir í notkun stafrænnar tækni í námi og kennslu. Margir höfðu leitað til annarra kennara um aðstoð og leiðsögn og hafa má í huga að leita má upplýsinga og leiðsagnar á netinu, líka til kennara við aðra skóla og netsamfélaga kennara um tiltekin áhugasvið. Vísbendingar um slíka samhjálp og sjálfsbjargarviðleitni kennaranna má finna í opnum svörum sem ekki eru viðfang pessarar greinar.

\section{Áskoranir og tækifæri}

Hér hefur verið komið á framfæri helstu tölulegum niðurstöðum úr könnun okkar meðal grunnskólakennara vegna veirufaraldurs og peirra breytinga sem urðu á starfi grunnskóla af hans völdum vorið 2020. Athyglinni er beint að stafrænni tækni og hvernig henni var beitt, og pá einkum í blandaðri kennslu eða netkennslu. Við greinum umtalsverða breytingu á kennsluháttum í faraldrinum og ljóst er að margir í hópi kennara líta svo á að hann geti haft veruleg áhrif á próun 
kennsluhátta til lengri tíma. Mikilvægt er að skoða áskoranir, álitamál, ávinning og tækifæri tengd tækninotkun í grunnskólastarfinu í pessu samhengi.

Í megindráttum leiðir rannsóknin í ljós að skólar og heimili voru ekki að öllu leyti illa í stakk búin til að mæta tæknilegum kröfum sem fylgdu faraldrinum. Leiða má að pví líkur að spjaldtölvuvæðing, einfaldar fartölvur og innleiðing námsumsjónarkerfa, samfélagsmiðlar og ör próun fartækni, samfélög kennara á netinu og reynsla í hópi nýliða, menntabúðir og kennsluráðgjöf, svo eitthvað sé nefnt, hafi á liðnum árum leitt til aukinnar tækninotkunar í skólum og færni á tæknisviðinu frá pví sem var fyrir tæpum áratug síđan (Skúlína Hlíf Kjartansdóttir o.fl., 2020; Sólveig Jakobsdóttir o.fl., 2014). Niðurstöður endurspegla pó vel að staðan er misjöfn eftir kennurum og aldursstigum og að efla parf bjargir, stuðning og leiðsögn sem nýst gætu kennurum í pessum efnum. Dá parf að gæta að viðkvæmum hópum sem búa við misjafnar aðstæður og stuðning á heimilum og leita leiða fyrir kennara til að koma sem best til móts við pá nemendur. Huga parf að starfspróun kennara og annarra faghópa í skólunum hvað snertir blandaða kennslu og netkennslu og gera verulegt átak í peim efnum.

Áhugi kennara á einingabærri menntun á háskólastigi er eftirtektarverður enda purfa tækifæri til menntunar, námskeið og leiðbeiningar að vera sem aðgengilegust um leið og hvatt er til jafningjafræðslu. Hlutverk kennsluráđgjafa eða verkefnastjóra sem fást við upplýsingatækni í skólastarfi má líka telja mikilvægt líkt og nefnt var hér í upphafi og ráđa má af fyrri rannsóknum á notkun stafrænnar tækni í skólastarfi (Sólveig Jakobsdóttir o.fl., 2014; Torfi Hjartarson, 2005). Vel má hugsa sér samstarf háskóla, samtaka, stofnana og sveitarfélaga um opin netnámskeið og frekari próun fjarmenntabúða í símenntun kennara. Pá gæti slíkt samstarf falið í sér rannsóknir á kennsluháttum með tilliti til skólapróunar. Par mætti styðjast við próun leiðarlykla og alpjóðlegra matstækja (sjá t.d. European Commission, e.d.) eða hæfniramma sem vikið var að hér að framan (Redecker, 2017). Dýrmæt tækifæri gætu líka falist í samstarfi kennara og skóla við fyrirtæki sem fást við próun hugbúnaðar, kennslugagna og tölvuleikja.

Stefnumótun í menntamálum parf sífellt að endurskoða, ekki síst nú með tilliti til aukinnar áherslu á stafræna hæfni. Breytingar eru uppspretta nýrra hugmynda og í COVID-faraldrinum hafa kennarar glímt við og prófað ýmsa kosti sem gætu leitt til sveigjanlegri kennsluhátta og nýrra tækifæra í skólastarfi til lengri tíma. Kennarar í grunnskólum virðast margir bjartsýnir á að pað verði raunin. Deir stóðu í eldlínunni pegar umbylta purfti skólastarfinu með litlum fyrirvara, ekki síst á eldri stigum, leystu úr erfiðum kringumstæðum, tókust á við vandann með hjálp tækninnar og ruddu nýjungum braut. Nú er að læra af peirri reynslu og mæta nýrri pörf fyrir bjargir, stuðning og leiðsögn, starfspróun, menntun og rannsóknir sem hvatt gætu stjórnendur, kennara og annað starfslið grunnskóla til frekari dáða. 


\section{Online teaching and digital technologies at primary and lower secondary school level in times of the COVID-19 pandemic in 2020: Views of teachers and principals}

During the COVID-19 pandemic in 2020, an increased research focus on digital competence of teachers and learners and the development of distance and online learning and education has become vital for educational systems all over the world. In Iceland, most schools at primary and lower secondary level stayed open but with considerable restrictions in terms of social distance and number of people allowed in each location. Online teaching and learning increased substantially as a result, especially for students at lower secondary level (grades 8 to 10). Surveys were sent out in spring 2020 (survey was open April 27 to May 26) by the Educational Research Institute (ERI) at the University School of Education to start charting the effects of the COVID-19 situation on learners and schools at primary and secondary level. Researchers in this project group contributed questions, relating to the use of digital technologies and online learning, to surveys for school staff in 151 schools. The results introduced in this paper are based on the answers of 1770 staff members. Of this group, 1263 indicated that they were teachers, 188 school administrators, 257 special education teachers, and 180 instructors without a teaching license (participants could check more than one role). The majority of all participant groups (61-70\%) thought that the schools were very well (25-32\%) or rather well (36-39\%) equipped with digital technologies. Also, the majority (65-70\%) thought the staff was very well (15-27\%) or rather well $(38-53 \%)$ prepared to deal with increased online communication and distance education. Furthermore, a majority of all groups (56-77\%) thought students' technological access was sufficient for online communication and distance learning. The results indicated a large increase regarding blended and online learning. The teachers indicated that before the pandemic, $78 \%$ of their teaching was in the schools but only $19 \%$ of the teaching was web-supported and 3\% blended. Conversely, during the pandemic, 30\% indicated that teaching was mostly in the school, $28 \%$ web-supported, $18 \%$ blended, $13 \%$ mostly online, and $10 \%$ only online. The increase in online teaching and learning was considerable, for example, regarding online discussion and chat, students' social activities, teachers' instruction and demonstrations, and teachers' collaboration. About half of the teachers (53\%) reported an increase in online meetings (via Google Meet, Skype, Zoom or Teams) and over 40\% reported an increase in email use as well as in the use of learning management systems (such as Google Classroom, MySchool or Moodle). The teaching of some subjects was cancelled or reduced, for example arts and crafts, and in some cases ICT. The majority of all participant groups thought that the COVID-19 pandemic would change teaching and learning in their schools in the long-term/permanently. To plan for the future, many thought it was important to prepare teachers for increased online and distance education. Many staff members were interested in credit-courses focused on the practical use of distance technologies in teaching and learning. Although the majority of schools, teachers and learners appeared to have dealt well with increased online learning, there were considerable differences between schools and teachers. In open-ended questions, many teachers reported their worries about vulnerable students with a weak background regarding, for example, access to technologies. It is important to study how ready schools are to operate online and teachers to teach and work online and how digital competences of teachers and students in schools can be assessed and facilitated. Lessons should be learned from the evolving experiences for an intermediate period where school closures or restrictions for social gatherings may be set repeatedly while the virus spread is controlled. It is important to help shape a policy for the long-term development of online learning and teachers' and learners' digital competences.

Key words: Online learning, distance education, digital technologies, primary and lower secondary schools, COVID-19 


\section{Um höfunda}

Sólveig Jakobsdóttir (soljak@hi.is) er prófessor við Menntavísindasvið Háskóla Íslands. Hún lauk M.Ed.-prófi 1989 frá University of Minnesota og doktorsprófi frá sama skóla 1996 í kennslufræði með áherslu á tölvunotkun í menntun. Sólveig hóf störf við Kennaraháskóla Íslands 1997 og hefur stýrt Rannsóknarstofu í upplýsingatækni og miðlun frá stofnun stofunnar 2008. Rannsóknir hennar og kennsla hafa snúið að upplýsingatækni í námi og kennslu og fjar- og netnámi. ORCID ID: https:// orcid.org/0000-0002-4205-0888

Salvör Gissurardóttir (salvor@hi.is) er lektor við Menntavísindasvið Háskóla Íslands. Hún lauk cand.oceon.-prófi frá Háskóla Íslands 1981 og M.A.-prófi frá University of Iowa í námsefnisgerð og námshönnun með áherslu á tölvur í skólastarfi árið 1990. Salvör hefur starfað sem framhaldsskólakennari í Reykjavík og sem námsstjóri í tölvugreinum í grunnskólum og framhaldsskólum í Menntamálaráđuneyti og sem sérfræðingur í málefnum upplýsingasamfélagsins í Forsætisráðuneyti. Hún hóf störf við Kennaraháskóla Íslands árið 1991. Rannsóknir hennar og kennsla hafa tengst upplýsingatækni í námi og kennslu, opnu menntaefni (OER), netnámi, forritun, stafrænni sögugerð og tölvuleikjum. ORCID ID: https://orcid.org/0000-0001-5710-5151

Skúlína Hlíf Kjartansdóttir (shk@hi.is) er aðjunkt við Menntavísindasvið Háskóla Íslands. Hún lauk B.Ed.-prófi í uppeldis- og kennslufræði og diplómanámi í handmenntum frá Kennaraháskóla Íslands, B.A.-prófi í prívíddarhönnun frá Camberwell College of Arts og meistaraprófi í myndlist/skúlptúr frá Wimbledon College of Art / Kingston University. Skúlína hefur starfað sem kennari og stjórnandi við grunn- og framhaldsskóla. Hún leggur stund á doktorsnám við HÍ. Helstu viðfangsefni hennar í kennslu og rannsóknum eru uppeldis- og menntunarfræði, list- og hönnunarmenntun, tæknimennt og upplýsingatækni í skólastarfi, fjölhátta læsi, menntastefna og framkvæmd hennar. ORCID ID: https://orcid.org/0000-0001-6817-5462

Svava Pétursdóttir (svavap@hi.is) er lektor við Menntavísindasvið Háskóla Íslands. Hún lauk B.Ed.-prófi frá Kennaraháskóla Íslands 1989 og doktorsnámi frá University of Leeds 2012. Doktorsritgerð hennar bar titilinn Using information and communication technology in lower secondary science teaching in Iceland. Rannsóknir hennar eru á sviði upplýsingatækni í skólastarfi, starfssamfélaga kennara og náttúrufræðimenntunar. ORCID ID: https://orcid.org/0000-0002-1206-8745

Torfi Hjartarson (torfi@hi.is) er lektor við Menntavísindasvið Háskóla Íslands. Rannsóknir hans beinast að skapandi vinnu með stafræna tækni í sveigjanlegu skólastarfi, námsefnisgerð og hönnun bygginga fyrir verkefnamiðað nám. Hann hóf sinn feril sem námsefnishöfundur, lauk meistaranámi frá University of Oregon 1991, stýrði Gagnasmiðju Kennaraháskóla Íslands, veitti Kennarafélagi Kennaraháskóla Íslands forystu og var í hópi ritstjóra sem stóð að stofnun Netlu - Veftímarits um uppeldi og menntun. ORCID ID: https://orcid.org/0000-0003-4382-6331

\section{About the authors}

Sólveig Jakobsdóttir (soljak@hi.is) is a professor at University of Iceland School of Education. She completed an M.Ed. degree in instructional systems and technology in 1989 from University of Minnesota and a doctoral degree from the same institution in 1996, focusing on school computer use. Sólveig started work at Iceland University of Education in 1997 and has led RANNUM - Centre for Educational Research on ICT and Media from its foundation in 2008. Her research and teaching has been on ICT in education, and online and distance teaching and learning. ORCID ID: https://orcid.org/0000-0002-4205-0888. 
Salvör Gissurardóttir (salvor@hi.is) is a lecturer/assistant professor at the School of Education, University of Iceland. She completed a Cand. Oecon degree from the University of Iceland in 1981 and an M.A. degree in instructional design and technology from the University of Iowa with emphasis on computers in education in 1990. Salvör has served as a secondary school teacher in Reykjavík and was a director of studies at the Ministry of Education in computers and computing in primary and secondary schools in Iceland and a department specialist in a task force relating to the information society in The Prime Minister's Office. She started work at University of Iceland School of Education in 1990. Her research and teaching has been on ICT in education, online teaching and learning, Open Educational Resources (OER), video games, digital storytelling, programming and coding. ORCID ID: https://orcid. org/0000-0001-5710-5151

Skúlína Hlíf Kjartansdóttir (shk@hi.is) is an adjunct at the University of Iceland / School of Education. She holds a B.Ed. degree, and a diploma in crafts education from the Iceland University of Education, a B.A. degree in 3D Design from Camberwell College of Art and a master's degree in art / sculpture from Wimbledon College of Art / Kingston University. Skúlína has served as a teacher and manager at primary, lower secondary and upper secondary schools. She is currently studying for a Ph.D. at the University of Iceland. Her teaching and research interests include art \& design education, technology education, ICT in education, multimodal literacy, educational policy and practice. ORCID ID: https://orcid.org/0000-0001-6817-5462

Svava Pétursdóttir(svavap@hi.is) is a lecturer/assistant professor in the School of Education, University of Iceland. She completed a B.Ed. degree from the Iceland University of Education in 1989 and a doctorate in education from the University of Leeds in 2012. The title of her thesis is Using information and communication technology in lower secondary science teaching in Iceland. Her research interests are in the field of ICT in education, teachers' professional development and science education. ORCID ID: https://orcid.org/0000-0002-1206-8745

Torfi Hjartarson (torfi@hi.is) is a lecturer/assistant professor at the School of Education, University of Iceland. His research interests include creative applications of digital media in flexible school practice and the design of learning materials and physical learning environments for project- based work. He started out as a curriculum textbook writer, completed an M.Sc. degree at the University of Oregon in 1991, directed an IT and Media Center at the Iceland University of Education, led the teacher association of that institute and was one of the founding editors of Netla - Online Journal on Pedagogy and Education. ORCID ID: https://orcid.org/00000003-4382-6331 


\section{Heimildir}

Allen, I. E., Seaman, J., Poulin, R. og Straut, T. T. (2016). Online report card - tracking online education in the United States. Babson Survey Research Group; Quahog Research Group. http://onlinelearningconsor tium.org/read/online-report-card-tracking-online-education-united-states-2015/

Allyson Macdonald, Torfi Hjartarson og Duríður Jóhannsdóttir. (2005). Upplýsinga- og samskiptatakni í starfi grunnskóla. Af sjónarhóli skólastjórnenda og tölvuumsjónarmanna [rannsóknarskýrsla á vegum NámUST]. Rannsóknarstofnun Kennaraháskóla Íslands.

Anna Björk Nikulásdóttir, Jón Guðnason og Steinpór Steingrímsson. (2017). Máltakni fyrir íslensku 2018-2022: Verkáatlun. Mennta- og menningarmálaráðuneytið. https://www.stjornarradid.is/library/03-Verkefni/ Menningarmal/M\%C3\%A11t\%C3\%A6kni\%C3\%A1\%C3\%A6tlun.pdf

Attewell, J., Balanskat, A. og Ayre, J. (2015). BYOD Bring your own device: A guide for school leaders. European Schoolnet. http://www.eun.org/resources/detail?publicationID=721

Ágúst Tómasson. (2015). Moodle næer og fjer: Blandað nám í samfélagsfraæi á unglingastigi [meistaraprófsritgerð, Háskóli Íslands, Reykjavík]. http://hdl.handle.net/1946/22956

Bannister, D. (2015). Exploring the creative use of tablets in schools: Observation visits final report. European Schoolnet. https://fcl.eun.org/documents/10180/275738/CCL_Observation+Report_FINAL-for+web. pdf/603a278f-6c13-4911-a0a1-744913f1e6d0

Bannister, D., Balanskat, A. og Engelhardt, K. (2013). Developing practical guidelines for 1:1 computing initiatives. European Schoolnet. http://files.eun.org/netbooks/1to1_Practical_Guidelines_EN.pdf

Cassels, D., Gilleran, A., Morvan, C. og Scimeca, S. (ritstjórar). (2016). Growing digital citizens: Developing active citizenship through eTwinning. European Schoolnet - Central Support Service for eTwinning. https:// www.etwinning.net/en/pub/publications.htm

European Commission. (e.d.). SELFIE. https://ec.europa.eu/education/schools-go-digital_en

European School Network. (2012). 1:1 pedagogy for schools. http://1to1.eun.org/web/acer

EVE Online. (2021). Project discovery. https://www.eveonline.com/discovery

Gebo Kano. (2021). Íslensk forrit fyrir iOS (Apple tæki). https://www.gebokano.com/\#icelandic

Gréta Björk Guðmundsdóttir og Hatlevik, O. E. (2018). Newly qualified teachers' professional digital competence: Implications for teacher education. European Journal of Teacher Education, 41(2), 214-231. https://doi.org/10.1080/02619768.2017.1416085

Guillén-Gámez, F. D., Mayorga-Fernández, M. J. og Álvarez-García, F. J. (2020). A study on the actual use of digital competence in the practicum of education degree. Technology, Knowledge and Learning, 25, 667-684. https://doi.org/10.1007/s10758-018-9390-z

Heiðarskóli. (2021). Skólanámskrá leik- og grunnskóla Hvalfjarðarsveitar-Heiðarskóli. https://skoli.hvalfjardarsveit. is/is/skolastarfid/skolanamskra

Ingvar Sigurgeirsson, Amalía Björnsdóttir, Gunnhildur Óskarsdóttir og Kristín Jónsdóttir. (2014). Starfshættir í grunnskólum - meginniðurstöður og umræða. Í Gerður G. Óskarsdóttir (ritstjóri), Starfshœettir í grunnskólum við upphaf 21. aldar (bls. 113-158). Háskólaútgáfan. https://opinvisindi.is/handle/20.500.11815/228

Kearney, C. og Gras-Velázquez, À. (2015). eTwinning 10 years on: Impact on teachers' practice, skills, and professional development opportunities as reported by eTwinners. Central Support Service for eTwinning; European Schoolnet. https://www.etwinning.net/downloads/eTwinningreport_EN.pdf

Kelentrić, M., Helland, K. og Arstorp, A.-T. (2017). Professional digital competence framework for teachers. Senter for IKT i utdanningen. https://www.udir.no/in-english/professional-digital-competence-frameworkfor-teachers/

Kópavogsbær. (e.d.). Markmið með spjaldtölvuinnleiðingunni. https://spjaldtolvur.kopavogur.is/upplysingar/

Kristín Jónsdóttir. (2020). Tengslin við heimilin trosnuðu merkilega lítið í fyrstu bylgju COVID-19: Sjónarhorn stjórnenda og grunnskólakennara. Sérrit Netlu 2020 - Menntakerfi og heimili á tímum COVID-19. https:// netla.hi.is/serrit/2020/menntakerfi_heimili_covid19/05.pdf 
König, J., Jäger-Biela, D. J. og Glutsch, N. (2020). Adapting to online teaching during COVID-19 school closure: Teacher education and teacher competence effects among early career teachers in Germany. European Journal of Teacher Education, 43(4), 608-622. https://doi.org/10.1080/02619768.2020.180965 0

Menntasvið Kópavogsbæjar. (2020). Skipulag fjarnáms. https://spjaldtolvur.kopavogur.is/wp-content/ uploads/2020/05/Skipulag-fjarnams.pdf

Menntavísindastofnun Háskóla Íslands. (2020). Áhrif COVID-19 á grunnskólastarf. https://mvst.rhi.hi.is/ grunnskoli_covid/

Oddur Ingi Guðmundsson. (2019). Smiðjan - skapandi skólastarf í próun: Tilraun um kennsluhatti í grunnskóla [meistaraprófsritgerð, Háskóli Íslands, Reykjavík]. http://hdl.handle.net/1946/34095

Picciano, A. G. og Seaman, J. (2007). K-12 online learning: A survey of U.S. school district administrators. Babson Survey Research Group; Hunter College - CUNY; The Sloan Consortium. https://doi.org/10.24059/ olj.v11i3.1719

Redecker, C. (2017). European framework for the digital competence of educators: DigCompEdu. Publication Office of the European Union. https://doi.org/10.2760/159770

Reglugerð um takmörkun á skólastarfi vegna farsóttar nr. 958/2020.

Ríkislögreglustjóri og sóttvarnalæknir. (2020, 25. maí). Heimsfaraldur - Landsácetlun: Viðbragðsácetlun Almannavarna, útgáfa 3.1. https://www.landlaeknir.is/servlet/file/store93/item29596/Vi\%C3\%B0brag \%C3\%B0s\%C3\%A1\%C3\%A6tlun\%20heimsfaraldur\%203.1\%2025052020.pdf

Ruth Jörgensdóttir Rauterberg og Anna Björk Sverrisdóttir. (2020). Reynsla og upplifun proskapjálfa í grunnskóla af áhrifum COVID-19 faraldursins á pjónustu við nemendur. Sérrit Netlu 2020-Menntakerfi og heimili á tímum COVID-19. http://netla.hi.is/serrit/2020/menntakerfi_heimili_covid19/06.pdf

Rúnar Sigpórsson. (2000). Fjarkennsla á Ströndum: Tilraunaverkefni i fjarkennslu milli Grunnskólans á Hólmavík og Broddanesskóla. Rannsóknastofnun Háskólans á Akureyri. http://staff.unak.is/not/runar/Ritskra/ Brodd_skyrsla.pdf

Rúnar Sigpórsson. (2003). „,.. pað eru alltaf leiðir“: Tilraun til fjarkennslu með fjarfundabúnaði milli Grunnskólans á Hólmavík og Broddanesskóla í Kollafirði veturinn 1999-2000. Netla - Veftímarit um uppeldi og menntun. https://netla.hi.is/arsrit-2003/

Salvör Nordal, Sigurveig Dórhallsdóttir og Eðvald Einar Stefánsson. (2020). Frásagnir barna á tímum COVID-19. Sérrit Netlu 2020 - Menntakerfi og heimili á tímum COVID-19. http://netla.hi.is/serrit/2020/ menntakerfi_heimili_covid19/07.pdf

Samband íslenskra sveitarfélaga. (2020, 15. mars). Sameiginleg yfirlýsing vegna áhrifa COVID-19 á skólastarf. https://www.samband.is/frettir/sameiginleg-yfirlysing-vegna-ahrifa-covid-19-a-skolastarf/

Sigurður Haukur Gíslason. (2017). Innleiðing á spjaldtölvum i starf grunnskóla: Handbók fyrir sveitarfélög og skólafólk [meistaraprófsritgerð, Háskóli Íslands, Reykjavík]. http://hdl.handle.net/1946/29207

Skúlína Hlíf Kjartansdóttir, Torfi Hjartarson og Svava Pétursdóttir. (2020). Of women pioneers and tiny experts of ingenuity. Frontiers in Education, 5. https://doi.org/10.3389/feduc.2020.00160

Sólveig Jakobsdóttir. (2020). Menntabúðir í starfspróun kennara: Geta pær virkað á netinu? Skólapræðir. https://skolathraedir.is/2020/04/09/menntabudir-i-starfsthroun-kennara-geta-thaer-virkad-a-netinu/

Sólveig Jakobsdóttir, Anna Kristín Sigurðardóttir, Tryggvi Thayer, Svava Pétursdóttir, Dorbjörg St. Porsteinsdóttir og Hanna Rún Eiríksdóttir. (2013). EducationPlaza - Teachers' professional development. Í M. F. Paulson og A. Szucs (ritstjórar), EDEN 2013 annual conference. The joy of learning: Enhancing learning experience improving learning quality. Conference proceedings (bls. 975-986). European Distance and E-Learning Network.

Sólveig Jakobsdóttir, Hróbjartur Árnason, Kristín Dýrfjörð, Salvör Gissurardóttir, Sólveig Zophoníasdóttir og Svava Pétursdóttir. (2021). Menntabúðir í starfspróun kennara: Pær virka á netinu! Skólapræđir. https:// skolathraedir.is/2021/03/02/menntabudir-i-starfsthroun-kennara-thaer-virka-a-netinu/

Sólveig Jakobsdóttir og Skúlína Hlíf Kjartansdóttir. (2015). Spjaldtölvur í Norðlingaskóla - próunarverkefni. Lokaskýrsla. Menntavísindastofnun; RANNUM. http://skrif.hi.is/rannum/files/2016/01/Lokaskyrsla_ Nordlingaskoli_1okt2015jan2016.pdf 
Sólveig Jakobsdóttir, Torfi Hjartarson og Bergpóra Pórhallsdóttir. (2014). Upplýsingatækni í skólastarfi. Í Gerður G. Óskarsdóttir (ritstjóri), Skólastarf í grunnskólum við upphaf 21. aldar (bls. 277-322). Háskólaútgáfan.

Sólveig Jakobsdóttir og Duríður Jóhannsdóttir. (2010). Úttekt á fjarkennslu í framhaldsskólum. RANNUM; SRR Háskóla Íslands. http://hdl.handle.net/10802/523

Sólveig Jakobsdóttir og Puríður Jóhannsdóttir. (2018). The development of K-12 online and blended learning in Iceland. Í K. Kennedy og R. Ferdig (ritstjórar), Handbook of K-12 online and blended learning research (2. útgáfa, bls. 649-664). ETC Press. https://doi.org/10.1184/R1/6686813.v1

Sóttvarnalæknir. (2020, 28. febrúar). Fyrsta tilfelli COVID-19 kórónaveiru greinist á Íslandi. https://www. landlaeknir.is/um-embaettid/frettir/frett/item39280/fyrsta-tilfelli-covid-19-koronaveiru-greinist-a-islandi

Torfi Hjartarson. (2005). Upplýsinga- og samskiptatækni við grunnskóla í bæ í nágrenni höfuðborgar. Í Allyson Macdonald, Torfi Hjartarson og Duríður Jóhannsdóttir (ritstjórar), Upplýsinga- og samskiptatakni i starfi grunnskóla. Af sjónarhóli skólastjórnenda og tölvuumsjónarmanna [rannsóknarskýrsla á vegum NámUST] (bls. 41-53). Rannsóknarstofnun Kennaraháskóla Íslands.

Trausti Dorsteinsson, Tryggvi Guðjón Ingason og Guðrún Rósa Dórsteinsdóttir. (2006). Dreifmenntun i grunnskólum V-Bardastrandarsýslu. Rannsóknastofnun Háskólans á Akureyri. https://www.rha.is/static/ files/Rannsoknir/2006/Dreifmenntun.pdf

Vuorikari, R., Garoia, V. og Balanskat, A. (2011). Introducing Netbook pedagogies in schools: Acer- European schoolnet educational Netbook pilot. European Schoolnet. http://1 to1.eun.org/web/acer/evaluation

Wenger, E. (1998). Communities of practice: Learning, meaning, and identity. Cambridge University Press.

Wenger, E., White, N. og Smith, J. D. (2009). Digital habitats: Stewarding technology for communities. CPsquare.

World Health Organization. (2020, 11. mars). WHO Director-General's opening remarks at the media briefing on COVID-19 - 11 March 2020. https://www.who.int/dg/speeches/detail/who-directorgeneral-s-opening-remarks-at-the-media-briefing-on-covid-19---11-march-2020

Duríður Jóhannsdóttir og Sólveig Jakobsdóttir. (2011). Dreifmenntarverkefnið SnceVest 2008-2011: Efling grunnskóla á landsbyggðinni með dreifmenntun - úttekt. Menntavísindastofnun; RANNUM. http://skrif. hi.is/rannum/files/2011/09/ThuridurJohannsdottir_SolveigJakobsdottir_Sn\%C3\%A6Vest_mat_2011.pdf

Duríður Jóna Jóhannsdóttir og Sólveig Jakobsdóttir. (2020). Fjarkennsla og stafræn tækni í framhaldsskólum á tímum farsóttar vorið 2020: Sjónarhóll kennara og stjórnenda. Sérrit Netlu 2020 - Menntakerfi og heimili á tímum COVID-19. http://netla.hi.is/serrit/2020/menntakerfi_heimili_covid19/10.pdf

Sólveig Jakobsdóttir, Salvör Gissurardóttir, Skúlína Kjartansdóttir, Svava Pétursdóttir og Torfi Hjartarson. (2021).

Netkennsla og stafræn tækni í grunnskólum á tímum farsóttar vorið 2020: Sýn kennara

Netla - Veftímarit um uppeldi og menntun. Menntavísindasvið Háskóla Íslands.

Sótt af http://netla.hi.is/greinar/2021/alm/16

DOI: https://doi.org/10.24270/netla.2021.16 